NATIONAL

ACADEMY

$\mathrm{OF} \cdot \mathrm{SOCIAL}$

INSURANCE

\title{
Strengthening Unemployment Insurance for the 21st Century: A Roundtable Report
}

\author{
Stephen A. Woodbury \\ Michigan State University and W.E. Upjohn Institute \\ Margaret C. Simms \\ The Urban Institute
}

January 2011 



\section{NATIONAL \\ ACA D E M Y \\ $\mathrm{OF} \cdot \mathrm{SOCIAL}$ \\ INSURANCE}

\section{Table of Contents}

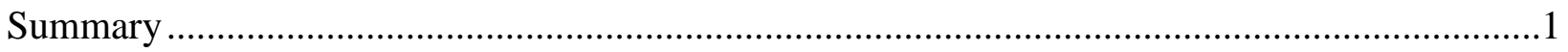

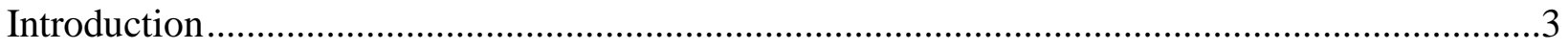

Panel 1: Unemployment Insurance Administration ................................................................5

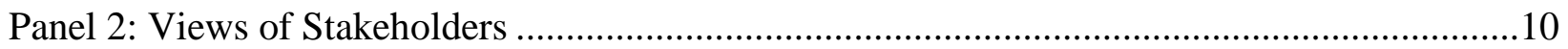

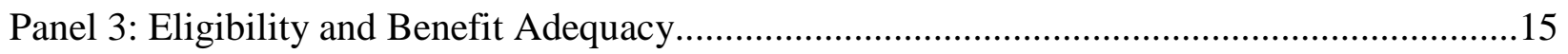

Panel 4: The UI Payroll Tax: The Taxable Wage Base and Experience Rating..........................21

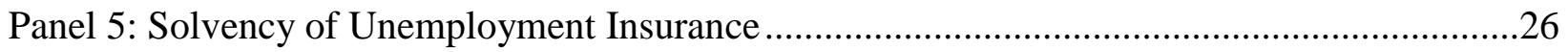

Panel 6: Getting Workers Back to Work ...........................................................................33

An Agenda for Future Research ....................................................................................

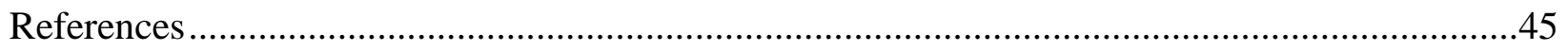

Appendices:

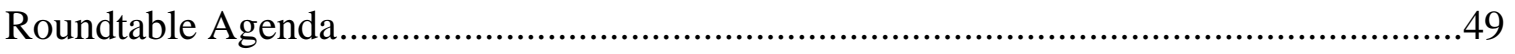

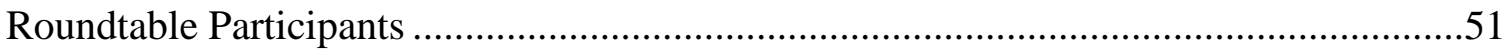

Additional documents from the roundtable-including overheads from the presentations-are available at http://www.nasi.org/events/125/event-presentations-materials.

\section{Acknowledgements}

The National Academy of Social Insurance (NASI) and the authors gratefully acknowledge the U.S. Department of Labor, the Annie E. Casey Foundation, the W.E. Upjohn Institute for Employment Research, and the DirectEmployers Association for their support of the roundtable. We also thank Rich Hobbie and Ralph Smith for detailed and helpful comments on a draft of this report . 



\section{Summary}

This report summarizes the proceedings of a national roundtable on "Strengthening Unemployment Insurance for the 21st Century," convened by the National Academy of Social Insurance (NASI) in Washington, DC, on July 13, 2010. The roundtable was prompted by the seventy-fifth anniversary of the Social Security Act, which established Unemployment Insurance (UI) as a state-federal program in 1935, and by the Great Recession, which has placed unusual demands and stress on the UI program.

The roundtable brought together about 70 government officials, legislative staff, researchers from think tanks and academia, representatives of employers and workers, and other interested parties. The day was organized into six panels, each on a specific aspect of the UI program, plus a final session during which attendees suggested UI program reforms. The first six panels started with brief presentations by at least two UI experts, then moved on to a discussion period and comments from others attendees. (Overheads from the presentations are available from the NASI website at www.nasi.org.) The topics considered and central points raised in the six panels were:

1. Unemployment Insurance Administration: Even before the Great Recession, the performance of the UI system was in long-term decline. The infrastructure of the system is aging, and funding to upgrade the system's information technology is not available. UI administrators believe the funding for current administration of the system, including delivery of reemployment services, is inadequate. The budgeting process for UI administrative funding needs to be reexamined.

2. Views of Stakeholders: Surprisingly, perhaps, representatives of both employers and workers agree on most issues relating to the UI system. For example, they agree on the need to add funding for administering the UI system and reemployment services. They also agree that the structure and funding of extended benefits should be overhauled, and that the federal government will need to provide relief to states that have borrowed because their trust funds became insolvent during the current slump.

3. Eligibility Requirements and Benefit Adequacy: Two major changes in the labor market have occurred since UI was adopted. First, nearly half of all workers are now women, and because women are more likely than men to have nontraditional working arrangements, they are often ineligible for UI even though they have adequate earnings histories. Second, the percentage of unemployed workers who have permanently lost their jobs has increased, and existing UI benefits and reemployment services are inadequate to address the problems these workers face. Critics of UI believe these changes require UI program reform.

4. The UI Payroll Tax: The Taxable Wage Base and Experience Rating: The wage base on which UI payroll taxes are collected is narrow and fixed (that is, not indexed to wages) both at the federal level and in most states, which has two implications. First, because the burden of the payroll tax tends to fall on workers, the tax is regressive. Second, UI tax revenues rise more slowly than wages, which leads to lower UI trust fund balances, greater likelihood of insolvency when a recession hits, and pressure to reduce benefits. Increasing the taxable wage base would mitigate both problems. 
5. Solvency of Unemployment Insurance: As of September 2010, the UI trust funds of 31 states were insolvent, and these states had borrowed over $\$ 39$ billion from the federal government to pay UI benefits. The need to borrow reflects a move away from "forward funding" of UI, which in turn has reduced the ability of UI to serve as an automatic stabilizer during a recession. Most solvent states have a taxable wage base that is indexed to wages, which suggests that indexing the wage base could improve both forward funding and program solvency.

6. Getting Workers Back to Work: Participants agreed that reemployment services are an essential part of UI: Funding for these services should be increased, and different reemployment strategies are required during a recession than in normal times. Usually, it makes sense to conduct eligibility review interviews and require claimants to report for services like testing and assessment as a condition of continued benefit receipt. In a weak labor market, labor demand strategies such as work sharing, wage insurance, and wagebill subsidies are more likely to succeed.

The goal of the roundtable was to begin the process of producing a synthesis of our current knowledge on UI, a proposed research agenda, and new ideas and approaches for strengthening UI for the twenty-first century. The agenda for future research is included as a final section of this report. A separate report will summarize the final session of the roundtable, during which attendees suggested UI program reforms and innovative approaches for addressing challenges facing the UI system. 


\section{Introduction}

Unemployment Insurance (UI) was established in the United States in 1935 - seventy-five years ago - under the Social Security Act. It is a unique state-federal program: Each state conducts a separate program with its own payroll tax system, eligibility criteria, benefit amounts, and potential length of benefits, under the guidance of the U.S. Department of Labor.

Interest in UI rises and falls predictably with the state of the economy. Between August 1994 and August 2008, the national unemployment rate exceeded 6 percent in just five months (May through September 2003) and never rose above 6.3 percent. Discussion in the popular press of a "new economy," in which macroeconomic booms and busts no longer occurred, relegated unemployment to secondary status on the list of social problems.

That changed with the onset of the Great Recession in 2008. During 2008-2009, employment fell by 8.4 million, or 6.1 percent - more than in any previous post-war recession. Also, the national unemployment rate rose from an average of 5.1 percent during 2004-2008 to more than 9 percent during 2009-2010.

The dramatic increase in the volume and duration of UI claims quickly depleted the UI trust funds of many states, so that by September 2010, the trust funds of 31 states were insolvent, and the federal government had loaned over $\$ 39$ billion to these states so they could continue paying UI benefits. In addition to the increased volume of regular state claims, implementation of a federal emergency extended benefits program (Emergency Unemployment Compensation, or EUC-08) severely strained the system. Increased workloads caused the timeliness of payments to slip and slowed the adjudication of disputes over claims.

In short, the Great Recession has cast a glaring and sometimes unflattering light on the UI system. Ironically, though, many of the problems raised by UI stakeholders have little to do with the program's performance in recession and much to do with long-term changes in labor markets. For example:

- Permanent layoff unemployment has become more common and temporary layoff unemployment less common. Concurrently, the average duration of an unemployment spell has increased. How well does the UI program serve permanent job losers and their needs for reemployment services?

- Married women and single women with children have increased dramatically as a proportion of the labor force since the UI program was established. But because women are more likely than men to have nontraditional work arrangements, they often find they are ineligible for UI. For example, workers seeking part-time jobs and workers who quit a job to follow a spouse who moves to take a new job are ineligible for UI in many states. These issues have become especially important since welfare reform and the passage of Temporary Assistance for Needy Families in 1996. How could the UI system be changed to better serve the needs of women, especially single women with children? 
- UI administrators and employers have long argued that the system used to allocate funds to the states for administering UI needs to be overhauled. They also argue that too little of the payroll tax revenue flowing to the federal government from the FUTA tax is returned to the states for improving administration of the UI system and providing employment services to workers. ${ }^{1}$ How can these problems be addressed?

The goal of the roundtable was to begin the process of producing a synthesis of our current knowledge on UI, a proposed research agenda, and new ideas and approaches for strengthening UI for the twenty-first century. We asked about a dozen UI experts to summarize key issues and present their views on one of six specific aspects of the UI program. The roundtable was organized into six hour-long panels, with time allowed for discussion following the presentations in each panel. This report reviews the presentations and discussions that followed. We treat each panel in succession, introducing the topic of the panel, summarizing the panelists' presentations, and describing the main points that participants raised during each discussion period. In trying to produce a cohesive narrative, we have edited the presentations liberally, and in describing the discussions, we have often reordered the sequence of questions and answers to produce a more logical flow.

Because a main goal of the roundtable was to produce an agenda of research that is needed to improve the UI system, we also summarize the participants’ suggestions for needed research in a final section. ${ }^{2}$

\footnotetext{
${ }^{1}$ The Federal Unemployment Tax Act (FUTA) establishes a federal payroll tax on employers. FUTA revenues finance administration of the UI program at the federal and state levels, the federal portion of the standby Extended Benefits program, loans to states with insolvent trust funds, and other related federal costs including employment services.

${ }^{2}$ The roundtable ended with a session moderated by Joseph Quinn of Boston College, during which participants were asked to present proposals for "sweeping reform" of the UI system. That session and the ideas presented there will be the topic of a subsequent brief, so we do not summarize it here.
} 


\section{Panel 1: Unemployment Insurance Administration}

Moderator: Margaret Simms

Institute Fellow, The Urban Institute

Gay Gilbert

Administrator, Office of Unemployment Insurance, U.S. Department of Labor

\section{Rochelle Webb \\ Administrator of Employment Administration, Arizona Department of Economic Security}

UI poses two problems in public finance. The first - how to fund the benefits received by workers - receives much attention from Congress and in the press whenever a recession occurs. Rising unemployment rates and longer spells of unemployment lead to greater UI benefit payments, strain state UI trust funds, and lead to calls for emergency benefit extensions. A second financing problem - how to fund the administrative apparatus that processes UI claims and ensures their accurate and timely payment - has received virtually no attention in the media, and yet it is equally important. Panel 1 addressed administrative financing; Panels 4 and 5 addressed the financing of benefits. In Panel 1, Gay Gilbert presented the federal perspective on UI administration, and Rochelle Webb presented the perspectives of a state administrator.

\section{Gay Gilbert}

Gilbert emphasized the importance of UI as an automatic stabilizer and pointed to the challenges of the current recession and of managing the federal emergency extended benefits program (EUC-08) that started in July 2008. She addressed five main points in her remarks:

- The UI program's performance measures are in long-term decline.

- The program's infrastructure is aging, and no funding source exists to improve it.

- Funding for the program's current administration is inadequate.

- Challenges exist in connecting UI claimants to reemployment services.

- Balanced reform of UI will require the participation of all interested parties.

The long-term decline in the UI program's integrity — particularly increased improper payments — is a serious concern that will require new strategies and policies. These new policies will require legislative reform. Gilbert suggested that the aging infrastructure of UI in the states - in particular computer systems that are 25-30 years old - is an important reason for the decline in measured performance and emphasized that no current funding source exists to replace those computers. She noted that, although federalization of the UI system is unlikely and probably not desirable, greater uniformity across the state programs would facilitate and reduce the costs of administering the system. ${ }^{3}$

\footnotetext{
${ }^{3}$ Chocolaad (2010) reports the results of a survey of the states on this question.
} 
A major concern for every state UI program is the inadequate and diminished funding for administering the program. Because funds for program administration come through annual appropriations and compete with other federal discretionary spending, these funds are not likely to increase significantly. Gilbert suggested that research on the impacts of the existing funding structure would be valuable.

It has proven difficult "to effectively connect UI claimants to the full range of reemployment services [available through] the workforce investment system." This difficulty arises from the lack of a clear directive regarding UI claimants in the Workforce Investment Act (WIA), rigidities in the way WIA funds can be allocated, and shrinking overall resources under WIA. Although the American Recovery and Reinvestment Act (the Recovery Act) included funding for reemployment services, those funds ran out on September 20, 2010. Researchers and practitioners have made substantial progress on how best to allocate funds for reemployment services - that is, which services should be offered to various groups of claimants. Still, this a field where additional research and collaboration among the states and the Employment and Training Administration could have a large payoff (Eberts and O’Leary 2002, Jacobson 2009).

Gilbert closed with the observation that solving the problems of the UI system will require statutory reform, and she expressed the view that reform will need to be comprehensive, not piecemeal. She emphasized that creating a balanced UI policy will require the participation and cooperation of all interested parties - representatives of employers and workers, as well as UI administrators - and should be informed by the best available research and information. She also suggested the need to consider a new national process and structure for "nurturing [this] balanced approach to UI policy" - something "less cumbersome" than the Advisory Council on Unemployment Compensation, which has been authorized since 1991 but has only been funded once, from 1993-1996. ${ }^{4}$

\section{Rochelle Webb}

Webb addressed a wide range of issues in her remarks, including the financing of both UI benefits and UI administration. She emphasized five main points about UI administration:

- The UI program is inherently complex and difficult to administer.

- The funds available to administer UI effectively, including funding to upgrade the UI infrastructure, have been inadequate.

\footnotetext{
${ }^{4}$ The Advisory Council on Unemployment Compensation (ACUC) was established under Section 908 of the Social Security Act, as amended by the Emergency Unemployment Compensation Act of 1991 (P.L. 102-164) with the goal of undertaking a comprehensive review of the UI system and making recommendations for improvement. The ACUC held hearings throughout the country, commissioned a wide range of research, and sponsored two research conferences. Its activities resulted in three annual reports (February 1994, February 1995, and January 1996), a set of recommendations (1996), four volumes of background papers (two in July 1995, two in January 1996), and two edited volumes of research papers (Bassi and Woodbury 1998, 2000).
} 
- Funding for reemployment services has also been inadequate.

- Measures for solving the administrative funding problem include providing incentives to states to modify their rules, making changes in the budgeting process, and restricting the use of FUTA revenues to UI and related workforce programs.

- Progress on the problems facing the UI system "will require collaboration, compromise, and commitment."

Webb observed that UI is complex even in normal times. In particular, states must work with each other in handling interstate claims, but differences among the states' UI laws create difficult administrative problems and "a nightmare for claimants attempting to navigate the process." The complexity of UI has been compounded recently by the EUC-08 program, ${ }^{5}$ by changes mandated under the Recovery Act (such as Federal Additional Compensation, which temporarily increased all recipients' weekly benefit amount by $\$ 25)$, and by changes that some states have voluntarily adopted in response to financial incentives offered under the UI Modernization provision of the Recovery Act. These changes include adoption of an alternative base period and changes in eligibility criteria. ${ }^{6}$

Even without these recent complications, federal funding to support administration of the UI system has been inadequate. In particular, the infrastructure of the system is antiquated, and the funds to support "a modern approach to self-service, improved call center operations, and sustained face-to-face contact in local offices” have not been made available. As a result, the quality of the program has deteriorated.

Webb also noted that funding for reemployment services should be increased. She suggested that research on the effectiveness of these services would be useful in deciding which should be funded.

Webb suggested three specific solutions to the UI administrative funding problem. First, she suggested that incentives should be provided for states to modify their rules and statutes so that interstate relations could be made simpler. Second, she suggested the need to change the budgeting process so that the models used by the U.S. Department of Labor and the Office of Management and Budget reflect "actual expenditures and inflation reported by state programs." Third, she suggested that FUTA revenues should be used exclusively for UI and related workforce programs, rather than applying FUTA funds to the federal unified budget. This would eliminate the discretionary budgetary treatment of UI administrative funding and greatly increase

\footnotetext{
${ }^{5}$ The Emergency Unemployment Compensation program, created by Congress on June 30, 2008, is the most recent in a series of federal "emergency" UI extensions providing additional UI benefits to individuals who have exhausted regular state UI benefits. EUC-08 is administratively complex, with four tiers and a reach-back provision. Federal emergency extensions differ from the standby EB program, which has existed since 1970 and is activated automatically when labor market conditions deteriorate in a state.

${ }^{6}$ Fendler (2010) and U.S. Department of Labor (2010) give up-to-date accounts of changes adopted by states under UI Modernization incentive payments.
} 
the resources available for workforce-related programs. Any or all of these changes will require collaboration and compromise among all interested parties.

\section{Discussion}

Margaret Simms started the discussion by asking Gilbert and Webb if they had comments on each other's remarks. Gilbert said she believes that she agrees with Webb on "quite a number of things," and that there is a critical role for the federal-state partnership. She also believes that strong participation by both business and labor is required in order to make good UI policy. But making federal policy and getting to federal legislation is a challenge, and she repeated that the Advisory Council approach is somewhat cumbersome.

Webb remarked that the elephant in the room is that state administrators can't bring about change on their own. UI is politically complex - even within the major political parties, viewpoints differ. Working toward the middle and finding common ground is a challenge.

Valerie Wilson (National Urban League) asked Webb why her state (Arizona) had not opted to make changes in its UI law that would make it eligible to receive UI Modernization incentive payments. Webb responded that the Arizona legislature saw the UI Modernization changes as an expansion of Arizona’s existing program that “didn’t fit the Arizona structure.”

In response to a question, Gilbert said that her agency had not attempted to determine how much of the decline in UI administrative performance was due to the recession as opposed to being part of a longer-term trend. However, she believes that challenges existed before the recession and will continue after the recession.

Stephen Woodbury (Michigan State University and W.E. Upjohn Institute) asked whether the model used in the budgeting process is outdated and in need of revision. Rochelle Webb replied that she believes the model is flawed, and her agency has worked on ways of improving it. Gay Gilbert said that the resource justification model is not perfect, but it is not the only (or even the most important) problem in financing UI administration. In her view, a bigger problem is that funding for UI administration is discretionary, so UI is competing with every other domestic discretionary program in the federal budget.

George Wentworth (National Employment Law Project) raised the issue of the outdated IT systems being used by the states, and suggested that the states really need to rebuild them from scratch. But doing so could cost \$3 to \$5 billion. He asked whether the problem is being addressed and whether there will be federal funding for the rebuilding of the states' IT systems. Gilbert replied that the resources do not exist to rebuild 53 separate systems, although the Reed Act distributions and Recovery Act funds have helped. ${ }^{7}$ The problem is that neither of those funding sources is steady. As a fallback, the Department of Labor has been encouraging the

\footnotetext{
${ }^{7}$ The Reed Act is part of the Employment Security Financing Act of 1954. It provides for returning funds from FUTA revenues to the states when the amount in the federal accounts for administration, state loans, and extended benefits exceed a specified level.
} 
states to form consortia, and two groups of four states have done so. Standardization of state laws would be very helpful but is difficult to accomplish.

Webb reemphasized the need to update the IT infrastructure of the UI system, and remarked that it will be difficult to raise UI administrative performance until a stable source of funding to upgrade the system is found. Gilbert remarked that research on the relationship between UI administrative funding and UI performance would be very useful. 


\section{Panel 2: Views of Stakeholders}

Moderator: Charles Betsey

Dean of the Graduate School and Professor of Economics, Howard University

\section{Douglas Holmes}

President, UWC—Strategic Services on Unemployment \& Workers' Compensation

\section{Andrew Stettner \\ Deputy Directory, National Employment Law Project}

The two parties with the strongest interest in the UI system are employers (because they pay the payroll taxes that finance the system) and workers (because they receive the benefits). In Panel 2, an employer representative, Douglas Holmes, and a worker representative, Andrew Stettner, each presented his views of UI, its problems, and possible solutions to those problems.

\section{Douglas Holmes}

\section{Holmes’s suggestions for improving the system can be grouped under four headings:}

- Reemployment: Additional funding should be made available for a wide range of reemployment services, including assessment, eligibility review interviews, and customized training.

- Administrative funding: Additional funding should be provided to improve the overall functioning of the system, particularly its integrity.

- Solvency: Relief for paying interest on federal loans should be extended through 2012, and provide relief from offset credit penalties under FUTA for 2010 and 2011.

- Benefits: The existing standby Extended Benefits (EB) program should be replaced by an extended benefits program that is fully funded by the federal government.

Holmes suggested that his proposals for improved reemployment policy would be positive for both employers and workers. On-the-job training and customized training have the potential to offer workers stable employment and higher earnings, and they also provide skilled workers to employers who demand them. Public-private partnerships will be necessary to make training efforts effective.

Holmes also advocated increased testing and assessment to improve the speed and success of job matching. Workers differ greatly, and these differences need to be recognized in helping them find reemployment. Also, reemployment services should encourage individual initiative by individual claimants. These approaches will be especially important during the phase-out of EUC-08. 
Holmes made numerous suggestions for improving the administration of UI. Funding should be made available to improve the integrity of the system — for example, by providing added funding for automated systems to avoid overpayments, and requiring employers to report the first day a former UI claimant works to the New Hire database. The latter would allow UI administrators to check when a claimant had found employment and would reduce overpayment errors. Additional funding should also be made available for eligibility review interviews and monitoring job search.

Financing the administration of UI and related functions needs to be reformed so that funding is adequate. Holmes suggested that the federal government typically returns only half the revenues it collects under FUTA, so ample funding should be available for the above proposals. He said that FUTA funds should be used solely for UI, the public labor exchange, labor market information, and other workforce development purposes. Ultimately, the FUTA tax should be set (reduced, presumably) so it is adequate to meet those functions alone. ${ }^{8}$

Many states have borrowed heavily from the federal government to pay their UI obligations, and repaying these debts will be difficult. It will be necessary to consider ways of easing the burden on employers in the indebted states. Under the Recovery Act, the states have been relieved from the requirement to pay interest on these debts through the end of 2010, and this relief should be extended through 2012. Also, the federal government should provide relief from offset credit penalties under FUTA for 2010 and 2011.

Finally, Holmes suggested replacing the existing standby Extended Benefits program, which is funded half by the states and half by the federal government, with an extended benefits program that is funded entirely by federal general revenues. The program should be triggered by the national unemployment rate. This suggestion is consistent with the belief that the consequences of macroeconomic downturns and the long spells of unemployment they create should be addressed by federal policy, not a state-federal program like UI.

\section{Andrew Stettner}

Stettner began with the observation that UI has succeeded in being an important countercyclical force during the current recession, due to the automatic stabilizing effects of the regular state program, the emergency benefit extensions, and adoption of incentives to liberalize eligibility under the Recovery Act. But despite this success, he sees three threats to the UI system:

- $\quad$ First, premature termination of the emergency Extended Benefits program (EUC-08) would be a mistake because it would cause UI recipiency to plummet.

- Second, the administrative infrastructure is failing, and as a result, the timeliness of first payments and handling of appeals has dropped to unacceptable levels.

\footnotetext{
${ }^{8}$ Rich Hobbie has pointed out that tax collections under FUTA are allocated to administer the states' UI and employment service programs, to fund the standby Extended Benefits program, and to fund loans to states that deplete their UI trust funds. When FUTA funds reach a statutory cap set under the Reed Act of 1954, the excess is distributed to the states.
} 
- Third, the UI system has been inadequately funded, and this has led to a solvency crisis that can only be remedied with federal leadership.

Stettner believes that UI has been an important source of countercyclical stimulus during the current recession. Two factors have been important to the countercyclical effectiveness of the program. First, EUC-08 has provided the longest potential duration of UI benefits (up to 99 weeks) in the history of the program. Second, the Recovery Act has given the states financial incentives to liberalize eligibility for benefits, and the result has been additional workers claiming and receiving benefits.

Despite this success, he sees three threats to the UI system. First, at the time of the roundtable, it appeared that Congress was about to end the emergency Extended Benefits program (EUC-08). He noted that long-term unemployment was at a record high and that no past emergency extension had been terminated when the national unemployment rate was as high as 9.5 percent. He viewed the termination as unacceptable because UI recipiency would plummet if it ended.

Stettner believes that extended benefits will be needed through 2012. He also believes that the existing standby EB program should be replaced with a new program that would extend benefits automatically in a recession, would have effective state and national triggers, and would be fully funded by the federal government. ${ }^{9}$

The second threat Stettner sees to UI is its failing administrative infrastructure. Since early 2009, less than 87 percent of new UI recipients have received their first payment within 14 days (or 21 days in states with a waiting week). Also, the appeals process has been unusually slow: Since 2001, fewer than 80 percent of appeals have been handled within 30 days. He suggested a range of solutions to these problems, including aggressive enforcement of timeliness standards by the U.S. Department of Labor, steady federal funding for administration and technological upgrades, and leadership from the U.S. Department of Labor in transplanting high-performance models from the private and public sectors to UI.

Stettner made three points relating to reemployment policy: Funding for reemployment programs like wage subsidies has been inadequate; recent temporary changes that have streamlined UI claimants' access to education and training programs should be made permanent; and it is important to allow workers to refuse unsuitable work without giving up their benefits.

The third threat to UI is inadequate funding, which has led to the insolvency of many state UI trust funds. The number of states maintaining adequate trust fund reserves (defined as reserves adequate to pay benefits for one year in the worst recession recorded in the state) dropped from 30 in 2000 to 19 in 2007. Even if the recession that started in late 2007 had been as modest as the recession of 1991, many state UI trust funds would have become insolvent. He noted that state UI tax rates are near an all-time low ( 0.7 percent on average) and that inadequate funding poses a serious threat to UI benefits and the safety net they provide. (Forty-four states cut benefits

\footnotetext{
${ }^{9}$ The Extended Benefits program, enacted by Congress in 1970, is a permanent (or standby) program that is intended to activate automatically in a recession and extend UI benefits to claimants who have exhausted their regular UI benefits. EB is funded half from state UI trust funds and half from FUTA revenues collected from the states.
} 
following the funding crisis of the early 1980s.) To return to its original approach of forward funding, he believes the federal government should significantly raise the taxable wage base and adopt solvency guidelines so that states maintain adequate trust funds.

\section{Discussion}

The discussion touched on a wide range of topics. Both Holmes and Stettner agreed they had similar views on many issues, although they did appear to disagree on taxation. Holmes remarked that the ability of a state to maintain economic competitiveness depends on keeping unemployment taxes from being increased so that employers survive and add employment to the economy. "Smart tax policy doesn’t penalize employers," he said. In response, Stettner argued that UI tax rates have declined over time, and that states have shown themselves unable to fund UI adequately. His solution is federal leadership in raising the UI taxable wage base.

Chris O’Leary (W.E. Upjohn Institute) asked how employers view customized training in comparison with hiring incentives, and Holmes replied that both customized training and the recently enacted Hiring Incentives to Restore Employment (HIRE) ${ }^{10}$ are beneficial to employers, but employers view customized training as a more complete package and more desirable because workers who receive it upgrade their skills and typically stay in the job for which they have been newly trained. So customized training leads to a good outcome for everyone, and employers would like to see more funding for it. Holmes also believes that public-private partnerships are needed to make customized training work effectively, both to make facilities for training available and to connect training programs with workers who could benefit.

Rochelle Webb agreed on the importance of customized training and that more funding would be useful; however, she believes that the 50-percent match required of employers may have been a deterrent to their take-up of customized training. She suggested that the 50-percent match is reasonable and that employers need to be willing to show the importance they place on training by sharing the cost.

Another participant asked whether a supply-side policy like training is an effective reemployment strategy in a recession and questioned whether jobs are currently unfilled because employers cannot find appropriately trained workers. (He also asked whether the kinds of training workers would receive would help them get jobs when the economy recovers.) Holmes replied that, although "you cannot train your way out of a recession," job openings are currently available for skilled workers. ${ }^{11}$ Moreover, in order to remain competitive, the country will increasingly need skilled workers who are problem solvers. He sees the current spike in community college attendance as a plus and something that bodes well for workers and the

\footnotetext{
${ }^{10}$ Under HIRE, an employer who hires someone who had worked at most 40 hours during the 60 days before they were hired is exempted from paying the employer's share of the Social Security payroll tax for that worker from March 18, 2010 through the end of the year. Also, if a worker is retained for a year, the employer may claim a business tax credit up to $\$ 1,000$ per worker.

${ }^{11}$ Whitehouse (2010) reports that many employers have had difficulty filling vacancies that require skilled workers, which tends to confirm this observation.
} 
economy in the long run. He feels the states should reexamine the policy of denying UI to workers who are attending college: “Either you're just looking for work when there aren’t jobs or you could be in school trying to better yourself. And I think it's probably better to be in school.”

O'Leary also asked about when and how to "wind down" the current EUC-08 program, which provides up to 99 weeks of benefits. Stettner replied that he feels it is too early to discuss winding down EUC-08 because hiring has not yet picked up adequately, and the benefits being provided are an important source of demand in the economy. Rochelle Webb and Roy Mulvaney (Administrator of the Montana Department of Labor and Industry) agreed with the view that UI is an important economic stabilizer.

Stettner also believes it would be sensible to make public service employment (PSE) available to workers who have exhausted their benefits, with two provisos. First, workers should not be required to take jobs that are deemed "unsuitable" for them given their skills and abilities. (He posed this as an issue of workers' rights.) Second, PSE has always been problematic because workers who have a PSE job may implicitly be taking work from an unsubsidized employee. So it is important to be specific about what is allowable under PSE in order to protect the existing workforce. But with those two caveats, he believes PSE can be useful as a way of giving workers skills, adding to their experience, and transitioning into paid employment.

Several roundtable participants, led by Neil Ridley of CLASP, suggested the need for an ongoing process for the purpose of discussing problems of the UI system, recommending solutions, and planning the future of UI. Ridley noted that the Advisory Council on Unemployment Compensation, which existed during 1993-1996, provided such a process and brought together the states, the federal government, employers, and workers. He also remarked that UI is off the radar screen until a recession hits, and then it is too late to correct the problems. Many of the problems we are seeing in this recession could have been foreseen and averted if a process had been in place beforehand. 


\section{Panel 3: Eligibility Requirements and Benefit Adequacy}

Moderator: Harry Holzer

Professor of Public Policy, Georgetown University and Institute Fellow, The Urban Institute

Luke Shaefer

Assistant Professor, University of Michigan School of Social Work

\section{Till von Wachter}

Associate Professor of Economics, Columbia University

Even before the current recession, at least two labor market trends suggested the need to broaden eligibility for UI and to consider changes in the benefits provided by the UI program. First, the welfare reforms of 1996 led to an influx of low-wage workers, especially single mothers, into the labor market, which implied that a growing number of low-wage workers would be claiming and relying on UI during spells of unemployment. Indeed, this influx of low-wage single mothers following welfare reform can be seen as part of the larger growth of female labor force participation, which is the single most important labor market trend of the last century. Second, the incidence of temporary layoff unemployment - layoffs in which a worker knows he or she will be recalled - has fallen over time, while the incidence of permanent job loss has increased. Consequently, the average duration of an unemployment spell has trended upward over the last 40 years. In addition, many observers of the UI program have been disturbed that the UI recipiency rate has declined over time. To what extent could changes in eligibility criteria reverse this trend? Would such changes be desirable? Panel 3 addressed both UI eligibility and benefit adequacy.

\section{Luke Shaefer}

Shaefer's presentation addressed the relationship between UI (a social insurance program) and two key means-tested welfare programs: cash assistance to low-income households (under Aid to Families with Dependent Children [AFDC] and Temporary Assistance to Needy Families [TANF]) and food stamps. He also discussed research on the UI eligibility of low-education single women. His main points included the following:

- Means-tested income support programs have changed substantially during the past 20 years, and these changes have important implications for UI.

- In particular, since 2000, UI has been a more important source of benefits for loweducation single mothers than has welfare (AFDC or TANF).

- Although more than three-quarters of low-education single mothers who entered unemployment were monetarily eligible for UI in 2001-2003, only about 30 percent met nonmonetary eligibility criteria. ${ }^{12}$

\footnotetext{
${ }^{12}$ Nonmonetary eligibility criteria are of two kinds. First, a claimant must have separated from an employer due to lack of work and through no fault of his or her own. For example, claimants who quit or
} 
- The disparity between monetary and nonmonetary UI eligibility of low-education single women may call for changes in the nonmonetary eligibility criteria.

The past 20 years have seen major changes in means-tested income support programs. The Earned Income Tax Credit has expanded, welfare has been reformed with the replacement of AFDC by TANF in 1997, public health insurance to poor children has expanded through the SCHIP program, and eligibility for food stamps (now the Supplemental Nutrition Assistance Program, or SNAP) has been liberalized. A main goal of these changes has been to reduce the dependence of low-income households on income transfers and to create an incentive for loweducation workers to gain employment and support themselves through work. The greater reliance of low-income households on market work suggests that these same workers may in the future depend more on the UI system for their consumption needs.

Shaefer's work with the Survey of Income and Program Participation (SIPP) has shown that since 2000, more low-education single mothers who entered unemployment have received UI than welfare (TANF). As Figure 1 shows, in 2005 almost 30 percent of these women received UI, whereas less than 15 percent participated in TANF. So the relative importance of UI in providing income to low-education single mothers has increased over time.

Figure 1.

\section{Program Participation of Low-Education Single Mothers Entering Unemployment}

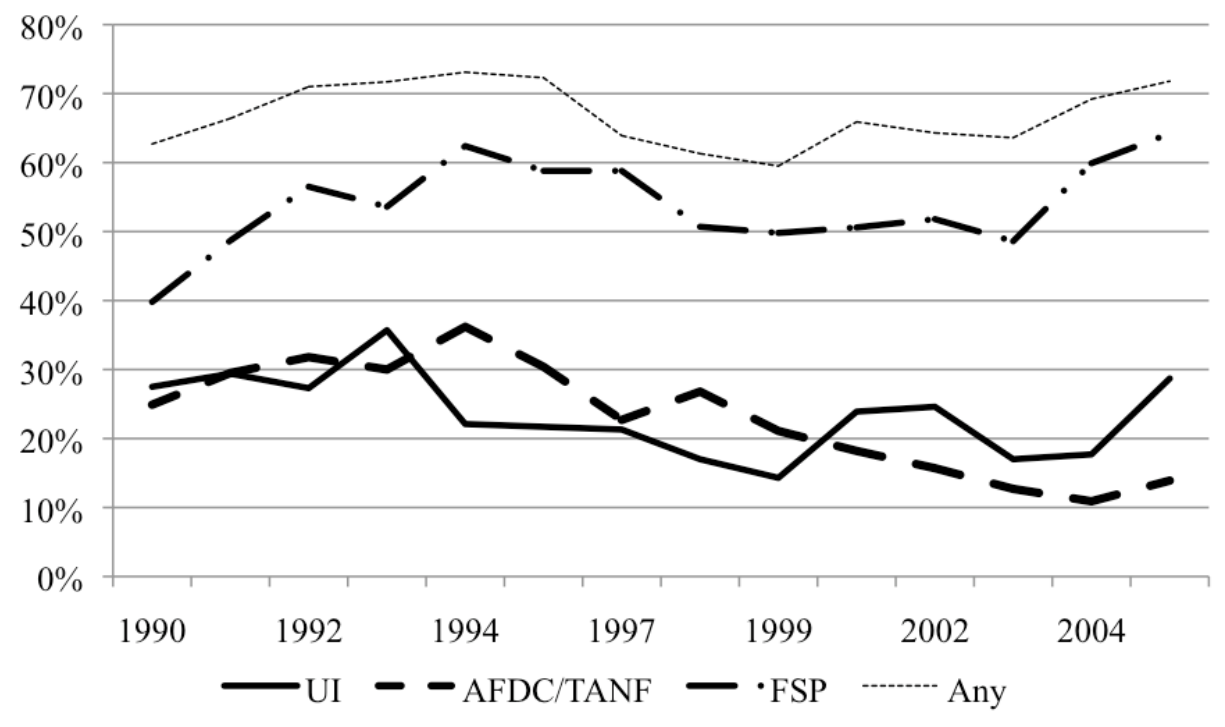

Source: Shaefer and Wu (2010), analysis of a pooled sample of the 1990-2004 Survey of Income and Program Participation panels.

are discharged for cause are ineligible. Second, a claimant must be able, available, and searching for work (full-time work in many states). For example, claimants who are in full-time training have traditionally been ineligible, on the grounds they are unavailable for work. 
Shaefer's estimates suggest that, although more than three-quarters of low-education single mothers were monetarily eligible for UI in 2001-2003, only about 30 percent met nonmonetary eligibility criteria. Low-education workers have been more likely than higher-education workers to be nonmonetarily ineligible for either of two reasons. First, low-education workers have been more likely to work part-time, and before 2008, UI claimants seeking part-time work were ineligible for benefits in all but four states. ${ }^{13}$ Second, low-education workers are more likely to separate from their employer for reasons other than layoff due to lack of work (for example, they may have quit or been discharged for cause).

The increased labor force participation of low-education women and other nontraditional workers has suggested to worker advocates that eligibility criteria for UI should be relaxed to accommodate these workers. This view has been implemented under the Recovery Act, which provides incentives to the states to loosen nonmonetary eligibility in ways that would increase the likelihood that low-education workers are eligible for benefits.

Finally, Shaefer has estimated that, among low-education single mothers who were eligible for UI in 2001-2003, only 46 percent actually received benefits. He suggested that an outreach program to ensure that low-education workers understand UI eligibility would be a reasonable policy for increasing the effectiveness of UI in this population.

\section{Till von Wachter}

Von Wachter's remarks focused on the adequacy of UI benefits and their duration. He made four main points:

- The existing structure of UI benefits is adequate to compensate workers who experience short spells of unemployment, but is inadequate for those who suffer long spells and large earnings losses.

- The existing method of extending benefits during a recession is incomplete and should be reformed.

- In devising an extended benefits program, the policy dilemma is the need to balance compensation for workers who have suffered large losses against the disincentive effects of providing benefits for a long period of time.

- Coordinating extended benefits with job search assistance and training, and varying benefits with workers' characteristics and the length of the unemployment spell, could mitigate the disincentive effects of extended benefits.

\footnotetext{
${ }^{13}$ Since 2008, 19 states have amended their UI statutes or modified their regulations so that UI claimants seeking part-time work would be eligible for benefits. They did this in response to financial incentives offered by UI Modernization. Still, two-thirds of the U.S. population live in states where part-time job seekers are UI-ineligible because states where part-time job seekers are UI-eligible tend to be small. Of the 15 largest states, only Georgia, New Jersey, New York, and North Carolina allow part-time job seekers to receive UI.
} 
Von Wachter started with the observation that, in normal times and mild recessions, most unemployment spells are short, although even in normal times, some workers (especially dislocated workers, who tend to be older) suffer long spells of unemployment and large earnings losses. In a severe recession like the current one, long spells and large earnings losses become much more frequent. Von Wachter suggested that existing U.S. policy to address long-term unemployment is "incomplete" in at least two ways.

First, the U.S. lacks a reliable program that extends benefits to dislocated and other long-term unemployed workers during severe downturns. A substantial body of research suggests that the existing structure of UI benefits - with a 50 percent replacement rate and 26 weeks of benefits for the typical worker - is adequate for workers who experience short unemployment spells, but inadequate for those who suffer long spells and the accompanying large earnings losses. In particular, the optimal UI literature ${ }^{14}$ has suggested that the existing UI system probably overcompensates workers with short spells, and under-compensates those with long spells. The reason is that, in general, risk-averse workers would be willing to accept a lower weekly benefit in exchange for insurance that would partially cover their loss over a longer period of time.

Although the United States has had an automatic standby EB program since 1970, that program often fails to trigger when it would probably be desirable, and it was ineffective in the recessions of 1991-1992 and 2001. As a result, the United States has become increasingly reliant on emergency (ad hoc) extended benefits programs like the current EUC-08. Emergency programs have been difficult and costly to administer, confusing to recipients, and uncertain in their funding. These problems all suggest the need for reforms that would result in an effective program to insure workers against long-term unemployment in a downturn.

Second, U.S. policy for long-term unemployment is incomplete because the available reemployment services and training programs are inadequate. Long-term unemployed workers need either reemployment services to motivate them to search for and accept reemployment or training to give them the skills they need to become reemployed. Although reemployment services are given to workers who can be expected to experience long unemployment spells under the Worker Profiling and Reemployment Services program, and although training programs do exist under WIA, funding for such activities has been cut over the years, and most UI administrators and many others think they are inadequate. ${ }^{15}$

Extended benefits programs help to protect workers against the risk of long-term unemployment and large earnings losses, but they also create a disincentive to search for and accept reemployment.

\footnotetext{
14 "Optimal UI" refers to a system of UI - that is, a replacement rate and a potential duration of benefits - that balances the consumption-smoothing (or insurance) benefits of UI against its disincentive effects (or moral hazard). A growing economic literature has explored various UI systems and attempted to appraise them within this framework. Karni (1999) offers a review of the early optimal UI literature.

${ }^{15}$ Title I of the Workforce Investment Act of 1998 includes an Adult and Dislocated Worker Program, which may provide training and supportive services, but funding for training has been limited. Also, the Trade Adjustment Assistance (TAA) program provides training, services, and income support to workers who have been certified dislocated due to increased imports; however, TAA is targeted to a specific and relatively small group of workers.
} 
Addressing the problems faced by dislocated and long-term unemployed workers is important because, if nothing is done, long-term unemployed workers are likely to leave the labor force, apply for and receive benefits from other more costly programs (like Social Security Disability Insurance), or slip into poverty. However, it would be a mistake to allow UI to turn into a longterm income replacement or anti-poverty program, which is why coupling extended benefits with training and reemployment services is necessary. Other possibilities for reducing the disincentive effects of extended benefits include varying benefits with workers' characteristics and reducing benefits as spells of unemployment lengthen.

\section{Discussion}

Chris O’Leary pointed out that many countries provide Unemployment Assistance, or meanstested public assistance, to workers who exhaust UI without becoming reemployed. He asked whether such a program would be worthy of consideration for the U.S. Von Wachter responded that Germany has such a program, which provides benefits for two years after UI exhaustion, and some countries' programs provide benefits for even longer. Such a program is hard to imagine in the United States for political reasons, but other "exit strategy" programs, or programs that offer a path out of UI, might be considered. For example, Germany has a severance pay program that offers older workers a bridge to retirement. For younger workers, training or wage insurance (perhaps in the form of a reemployment bonus) are possible programs to consider.

Shaefer suggested that Unemployment Assistance could play an important role for low-education single mothers, about 30 percent of whom receive UI when they become unemployed. Although food stamps are still available to this group, cash assistance (now through TANF) has declined as a buffer for this group, and Unemployment Assistance could fill the gap.

George Wentworth (National Employment Law Project) raised the treatment of UI claimants who had quit without good cause or been discharged. He noted that many states used to disqualify these claimants for a fixed number of weeks, but now these workers are often disqualified until they find another job and requalify for UI. He asked about the treatment of such workers in other countries and whether any research exists on how such eligibility criteria have affected low-wage workers. Shaefer responded that he believes nonmonetary eligibility raises a set of issues that have not been examined carefully. The issues need new research, and he is interested in pursuing these questions.

Harry Holzer said he was surprised that so little had been said about the UI Modernization provisions under the Recovery Act. He asked whether research existed on the extent to which low-wage workers would become newly eligible for UI in states that adopted the liberalized eligibility criteria. Luke Shaefer mentioned that UI Modernization provides two separate financial incentives for change: It provides one payment to states that have adopted an alternative base period (or base period that uses recent wages to determine monetary eligibility), and it provides a second payment to states that have adopted at least two of four other specific provisions. ${ }^{16}$ Shaefer and von Wachter had not seen estimates of how many additional workers

\footnotetext{
${ }^{16}$ The four provisions are: (1) allowing payment of UI to claimants seeking part-time work, (2) not disqualifying claimants who separate from an employer for certain compelling family reasons, (3) allowing an additional 26 weeks of UI for exhaustees who enroll in approved training programs, and (4)
} 
will become eligible for UI as a result of the changes.

The discussion then turned to racial disparities in UI eligibility and participation. One participant pointed out that African Americans represent about 12 percent of the labor force but are 22 percent of the long-term unemployed. What do we know about the composition of UI recipiency by race and ethnicity? Rochelle Webb said she was not aware of statistics that would shed light on these issues, although many state UI systems do collect information on race and ethnicity. Luke Shaefer remarked that it would not be surprising to observe racial differences in UI recipiency, given that people of color are overrepresented in jobs in which workers tend not to receive UI. Another participant mentioned a study that found African Americans to have lower recipiency than would be expected, especially given that they are more likely to live in states where UI recipiency is above average. Rochelle Webb referred to an Urban League study on this topic (National Urban League 2010).

Virginia Reno (National Academy of Social Insurance) asked, "What happens to kids in singleparent families when the parent becomes unemployed?” She noted that a major shift in the social safety net for low-income families with children is the replacement of cash assistance with programs and benefits that are tied to employment, like the Earned Income Tax Credit, childcare subsidies, and employer-provided health insurance. The problem is that, when the parent loses her job, she also loses those employment-related benefits. Is UI enough to replace those lost benefits? Do we need a broader support program for low-income households with kids?

Till von Wachter noted that, in Germany, the UI replacement rate varies by family status and the number of children. UI in the United States is mainly an attempt to replace a fraction of lost earnings without regard to household composition, although some states do have dependents' allowances, and UI Modernization includes incentives for states to adopt dependents' allowances. Luke Shaefer noted that the Earned Income Tax Credit lacks the countercyclical effect of UI, although it might be possible to modify the EITC so that it did. For example, if the unemployment rate exceeded a threshold, households that received an EITC in the previous year could receive a supplementary benefit. Or if the EITC of a household fell due to job loss, the household could become eligible for a supplemental benefit.

Ralph Smith (formerly of the Congressional Budget Office) remarked that his work with the SIPP reinforced the idea that, for certain groups of workers, especially workers living alone or with no other earner in the family, the duration of UI seems inadequate. His work found that, even in non-recessionary times, single household heads often had not returned to work three or four months after their UI benefits had been exhausted, and these households were frequently in poverty. Harry Holzer closed by noting that research by Page, Stevens, and Lindo (2009) shows that job displacement of a parent has long-term adverse consequences for kids, especially those whose families were low-income to begin with. Direct services to children of displaced parents might be an additional avenue for dealing with these scarring effects.

having a weekly dependents' allowance of at least \$15 per dependent. Note that the first three of these ease nonmonetary eligibility. 


\title{
Panel 4: The UI Payroll Tax: The Taxable Wage Base and Experience Rating
}

\author{
Moderator: Erica Groshen \\ Vice President and Director of Regional Affairs at the Federal Reserve Bank of New York
}

Patricia Anderson

Professor of Economics, Dartmouth College

Gary Burtless

John C. and Nancy D. Whitehead Chair and Senior Fellow, The Brookings Institution

UI is financed by a payroll tax that, in most states, is collected entirely from employers. ${ }^{17}$ The tax base varies from state to state, but is no less than $\$ 7,000$ in any state - that is, each employer must pay a given tax rate on (at least) the first $\$ 7,000$ paid to an employee in a given year. ${ }^{18}$ The tax rate paid by an employer is "experience rated" - meaning it is higher for employers who have laid off more workers in the past and hence have been responsible for more benefits payments. John R. Commons, the University of Wisconsin economist whose colleagues and students were active in drafting the Social Security Act, advocated experience rating as a way to preserve jobs by making it costly to lay off workers (Blaustein 1993). In effect, experience rating was put forward as a form of job protection. In the last thirty years, several economists have shown empirically that experience rating does effectively discourage employers from temporarily laying off workers (see the following summary of Patricia Anderson's remarks). Panels 4 and 5 both addressed issues related to financing the UI system. Panel 4 focused on the payroll tax base, experience rating, and their implications for equity and efficiency.

\section{Patricia Anderson}

Anderson started with a brief description of the UI payroll tax. First, the tax rate paid by each firm is experience rated; however, experience rating is incomplete because the tax rate is capped, so that beyond some point, a firm can lay off additional workers without paying additional UI taxes. Second, most states have chosen a very low taxable wage base - indeed, only 17 states have a taxable wage base greater than $\$ 15,000$. Anderson then traced three consequences of these features of the payroll tax (see Anderson 2010 for further discussion and references):

- Because experience rating is incomplete, industries where employment is stable subsidize

${ }^{17}$ In Alaska, Pennsylvania, and New Jersey, a portion of the payroll tax is collected from employees.

${ }^{18}$ A state could set its taxable wage base below $\$ 7,000$, but it would pay a large effective penalty to the federal government if it did - the difference between actual FUTA tax revenues and the FUTA revenues that would be realized if the tax base were $\$ 7,000$ in the state. Accordingly, $\$ 7,000$ is an effective floor on the wage base that results from a financial incentive given to the states; the federal government does not set per se the minimum tax base. However, in both panels 4 and 5, participants often spoke as if the federal government did set the minimum tax base directly. 
the UI benefits of workers in industries where employment is more volatile.

- These inter-industry subsidies persist over many years, and even within an industry, some employers persistently pay more into the system than their laid-off workers draw in benefits (and vice versa).

- Because the taxable wage base is so narrow, and because the burden of the tax tends to fall on workers in the form of lower wages, the UI payroll tax is regressive - that is, low-wage workers effectively pay a disproportionate amount of their earnings in UI taxes.

Anderson focused on three consequences of incomplete experience rating and the low UI taxable wage base. First, incomplete experience rating creates a situation where, year after year, relatively stable industries (like trade; finance, insurance, and real estate; and services) pay more in UI payroll taxes than their workers draw in benefits. Similarly, workers in more volatile industries (like agriculture, mining, manufacturing, and construction) draw more UI benefits than their industries contribute.

Second, this persistent cross-subsidization weakens the insurance aspect of the UI system. UI is intended to protect workers against random or unpredictable downturns. Instead, workers in certain industries (and firms) receive benefits year after year, while workers in other industries effectively pay into the system without ever drawing benefits.

Although incomplete experience rating is the cause of cross-subsidies, Anderson argued that perfect experience rating is not the appropriate answer because it too would weaken the insurance aspect of UI. That is, under any insurance system, all insured agents pay a premium, and those who experience a bad event receive a benefit payment. If all the agents who experienced the bad event were then required to repay their benefit (as would happen under perfect experience rating), we would no longer have an insurance system.

One possible solution is Feldstein's (1978) suggestion that employers be fully charged for the first month of UI benefits received by their laid-off workers, regardless of their experience rating. Then, even employers at the maximum tax rate would incur additional charges when they lay off additional workers. This would create a disincentive for employers to temporarily lay off workers, but it would preserve the insurance aspect of the UI system by transferring benefits (and resources) from stable employers to the workers of employers who are suffering through a period of slack demand.

Third, the UI payroll tax is highly regressive due to a combination of two factors: The UI taxable wage base is very low, and the burden of the payroll tax tends to fall mainly on workers (see the summary of Gary Burtless's remarks and the Panel 4 discussion for more on this point).

Anderson presented an analysis of 1994 data (from Anderson and Meyer 2006) showing that workers in the lowest ten percent of the earnings distribution effectively pay about 2.8 percent of their earnings in UI payroll taxes, whereas workers in the top ten percent of the distribution pay just 0.3 percent. 
The same analysis (Anderson and Meyer 2006) also showed that increasing the taxable wage base would substantially reduce this disparity. For example, if the taxable wage base were raised to equal the OASI tax base ( $\$ 60,600$ in 1994 , the year of her analysis), workers in the lowest ten percent of the earnings distribution would effectively pay 1.3 percent of their earnings in UI payroll taxes, and workers in the top ten percent of the earnings distribution would pay 0.8 percent.

\section{Gary Burtless}

Burtless's talk focused on the regressivity of the UI payroll tax and its implications. His main points were:

- The UI taxable wage base is capped at a low level — less than $\$ 14,500$ in 32 states (including 9 of the 10 largest states).

- As a result, employers pay the same UI tax for a low-wage as for a high-wage worker.

- Because the burden of the UI payroll tax falls mainly on workers, the UI payroll tax is regressive - low-wage workers pay a disproportionate amount of their earnings to UI.

- Because the taxable wage base is fixed, UI tax revenues rise more slowly than wages, which leads to lower UI trust fund balances and pressure to reduce benefits.

- His remedy is to raise the federal UI taxable wage to half the Social Security wage base (about $\$ 53,000$ in 2010), and require states to raise their wage bases to at least that level.

Burtless reiterated that the UI taxable wage base is very low in most states. In 32 states (including 9 of the 10 largest), the wage base is less than $\$ 14,500$. As a result, employers pay the same UI payroll tax for a minimum-wage employee who works just 1,000 hours in a year (a halftime schedule) as for a high-wage employee who works full-time, full-year. The low wage base has three consequences.

First, the UI payroll tax is regressive. Empirical evidence suggests that most of the UI payroll tax is shifted back to workers in the form of lower wages; that is, workers bear most of the burden of the payroll tax. If so, then the UI payroll tax is regressive because it takes a far larger percentage of the earnings of a low-wage worker than of a high-wage worker. (For the extent of this regressivity, see the summary of Patricia Anderson's remarks above.)

The UI payroll tax looks somewhat better if we consider benefits received. Because low-wage workers are more likely to receive benefits due to their greater likelihood of job loss, and because those benefits replace a larger fraction of the lost earnings of a low-wage worker than of a high-wage worker, the regressivity of the tax may be mitigated somewhat, but the system remains regressive overall.

A second consequence of the low (and fixed) wage base is that it tends "to starve the system of revenues unless state legislatures increase the tax rate” on the taxable wage base. Because state 
legislatures are often reluctant to act, UI will be inadequately funded, and state UI trust funds will become insolvent when a recession hits. Moreover, "[s]tate legislatures facing low trust fund balances are tempted to hold down weekly benefits or tighten eligibility requirements,” reducing the effectiveness of UI.

Third, when the wage base is low, tax rates must rise to maintain UI tax revenues. As a result, the UI payroll tax "becomes the equivalent of a rising poll tax on new employment," discouraging job creation. Other economists, such as Hamermesh (1972), have noted that the low UI tax base causes employers to prefer high-wage workers to low-wage workers (because the payroll tax is a smaller percentage of wages paid to a high-wage worker) and gives them an incentive to have employees work more hours (so as to spread the fixed-per-worker UI payroll tax over more hours of work).

To remedy these problems, Burtless proposed that Congress raise the federal UI taxable wage base from $\$ 7,000$ to one-half the Social Security maximum taxable earnings, and then index the wage base to the Consumer Price Index (CPI-W), like the Social Security maximum. Congress should continue to require the states to set their taxable wage bases at no less than the federal base. This would bring the UI taxable wage base to \$53,400 in 2010 and fix it at half of Social Security maximum taxable earnings. Burtless suggested that this is a modest proposal, given that the UI taxable wage base and Social Security maximum taxable earnings were in fact the same when the two programs started in 1935.

\section{Discussion}

Douglas Holmes started by noting that participation in UI is incomplete, in that many workers who are eligible to receive benefits do not claim them. This is puzzling because economists generally assume that the UI payroll tax is effectively a tax on the worker, even though it is collected from employers. Perhaps workers' behavior doesn't reflect an awareness that the burden of the UI payroll tax falls on them because (in most states) the payroll tax is collected entirely from employers. In contrast, half of the Social Security payroll tax is collected from workers, who see their contributions. Participation in Social Security old-age insurance rate is far higher, which suggests that workers' behavior reflects an awareness that they pay for Social Security.

Patricia Anderson agreed that a smaller percentage of workers ever receive UI benefits than ever receive Social Security old-age benefits, and this raises the question of whether private reemployment accounts would make sense. A higher proportion of workers might use private accounts, and the overall outcome might be more efficient. Nevertheless, UI is insurance, and insurance is necessarily designed so that only a fraction of those who pay a premium experience a bad event and file a claim. Many drivers pay for car insurance all their lives but never have an accident or file a claim.

Gary Burtless noted that the disability and survivors’ components of Social Security function more like traditional insurance than the old-age component. That is, only a fraction of covered individuals ever collect benefits because relatively few individuals experience disability or the death of a spouse or parent. So the majority of people contribute without ever receiving benefits. 
This is similar to home insurance: We consider ourselves fortunate if the $\$ 200$ monthly premium we pay results in no payments over our lifetimes. This is insurance, and insurance doesn't have the characteristic that there will be "exact equality of contributions and benefits on the individual level.” If it did, it wouldn’t be insurance.

Rochelle Webb questioned the economists' assumption that the UI payroll tax is effectively paid for by workers. Although three states - Alaska, New Jersey, and Pennsylvania - do collect part of the UI payroll tax from workers, all other states collect the tax entirely from employers. How can economists justify their view that workers in effect pay the tax?

A lengthy discussion of payroll tax incidence followed. Patricia Anderson clarified and noted that economists are simplifying when they say the burden of the UI payroll tax is shifted entirely to workers in the form of a lower wage. Among competing employers, the average tax rate will be shifted to workers, but employers who incur above-average taxes will not be able to shift the excess to workers. For example, if an employer who faces a 5.4 percent UI tax rate is competing with an employer who faces a 1 percent rate, only the 1 percent will be shifted to workers in the form of a lower wage. The high tax-rate employer will not be able to shift the other 4.4 percent onto workers (by lowering the wage) because in a competitive labor market, the workers will be able to find an employer who does not impose a 4.4 percent penalty on their wages.

But in general, the incidence (or burden) of a payroll tax is the same whether it is collected from the employer or from the worker. The burden of a tax depends not on where it is collected, but rather on the market supply and demand elasticities. In particular, the tax burden falls more heavily on the less flexible party: If employers are readily able to adjust their demand for labor to a wage change, and workers are not able or willing to adjust their labor supply to a wage change, the tax burden falls more on workers, and vice versa. The burden of a tax falls on the less elastic (less flexible) side of the market, and is unrelated to where the tax is collected. ${ }^{19}$

Linda Lawson (National Governor's Association) asked about the national implications of raising the taxable wage base. When the tax base is increased, do benefits tend to rise? Are employers happy with the outcome? Would states lower their UI tax rates so that total revenue wouldn't change? Would trust funds be more solvent today if the wage base had been raised ten years ago?

Gary Burtless replied that, if the tax base were raised, states would lower tax rates so that total revenue would not change greatly. ${ }^{20}$ But indexing the maximum taxable wage would mean that, over time, revenues would increase to reflect increases in the Social Security average wage (or whatever wage index is used). So a state legislature would no longer need to act in order for UI payroll tax revenues to increase.

\footnotetext{
${ }^{19}$ Most principles of economics texts, such as Mankiw (2004, chapter 6), include a discussion of tax incidence.

${ }^{20}$ Rich Hobbie has pointed out that, in addition, tax rates would fall automatically as state UI trust funds are replenished. This would happen for two reasons. First, a state's UI payroll tax schedule shifts up when the state's UI trust fund falls, and vice versa. Second, special solvency taxes activate when a state's trust fund becomes negative, and these solvency taxes end when a state's trust funds became replenished.
} 


\title{
Panel 5: Solvency of Unemployment Insurance
}

\author{
Moderator: Ralph E. Smith
}

Former Chief of Employment and Income Security Policy, Congressional Budget Office

\section{Wayne Vroman}

Senior Fellow, The Urban Institute

\section{Rich Hobbie \\ Executive Director, National Association of State Workforce Agencies}

Most UI payroll tax collections are deposited in a state's UI trust fund, from which benefits are paid to workers. States vary greatly in how large a trust fund they maintain in relation to the benefits they are likely to pay in the future — that is, they vary in the degree to which they "forward fund" the system. In the current recession, the trust funds of 31 states have been inadequate to pay promised benefits, and those states have had to borrow from the federal government so that benefits can be paid. As of August 5, 2010, the loans amounted to $\$ 35.5$ billion. Critics have suggested that the insolvency of so many state UI trust funds shows that states have abandoned forward funding in favor of a pay-as-you-go approach to funding UI. Moreover, they argue that the abandonment of forward funding has hampered the ability of UI to serve as an effective automatic macroeconomic stabilizer. Panel 5 extended the discussion of UI financing started in Panel 4 and examined the relationship between specific features of UI payroll taxes and the solvency of the UI system.

\section{Wayne Vroman}

Vroman started with background on how the Great Recession has affected state UI trust funds. He then offered an analysis of the differences between states whose trust funds were solvent and those whose trust funds were insolvent. His main points included the following:

- The increase in unemployment claims during this recession is unprecedented.

- The result has been rapid depletion of states’ UI trust funds.

- States differ greatly in the solvency of their trust funds, and most states with solvent trust funds have a taxable wage base that is indexed to the state's average weekly wage.

- The long-term solution to the problem of UI solvency is for the federal government to mandate a substantial increase in the UI taxable wage base.

From the standpoint of UI solvency, 2008-2010 has been the "perfect storm.” The recession has been severe, UI trust fund reserves were already low by historical standards, and the downturn occurred during the second half of 2008, so it was a full year before the states' tax schedules increased in response to their depleted trust funds. 
Vroman noted that in the current recession, monthly continued claims grew by 170 percent compared with their pre-recession level. This increase is greater than in previous recessions going back to the mid 1970s. (In the mid-1970s recession, continued claims grew by 130 percent. In the recessions of the early 1980s, 1992, and 2001, they grew by 80 percent or less.) Regular UI benefit payments increased from \$32 billion in 2007 to $\$ 79.2$ billion in 2009 .

The sharp increase in UI benefit payments rapidly depleted the states' UI trust funds because trust fund reserves were lower than is usual at the start of a recession. As Figure 2 shows, in the years leading up to the Great Recession, the aggregate reserve ratio (that is, net trust fund reserves of all states combined as a percentage of their total payrolls) was less than 1 percent.

Figure 2.

Aggregate Reserve Ratio, 1960-2009

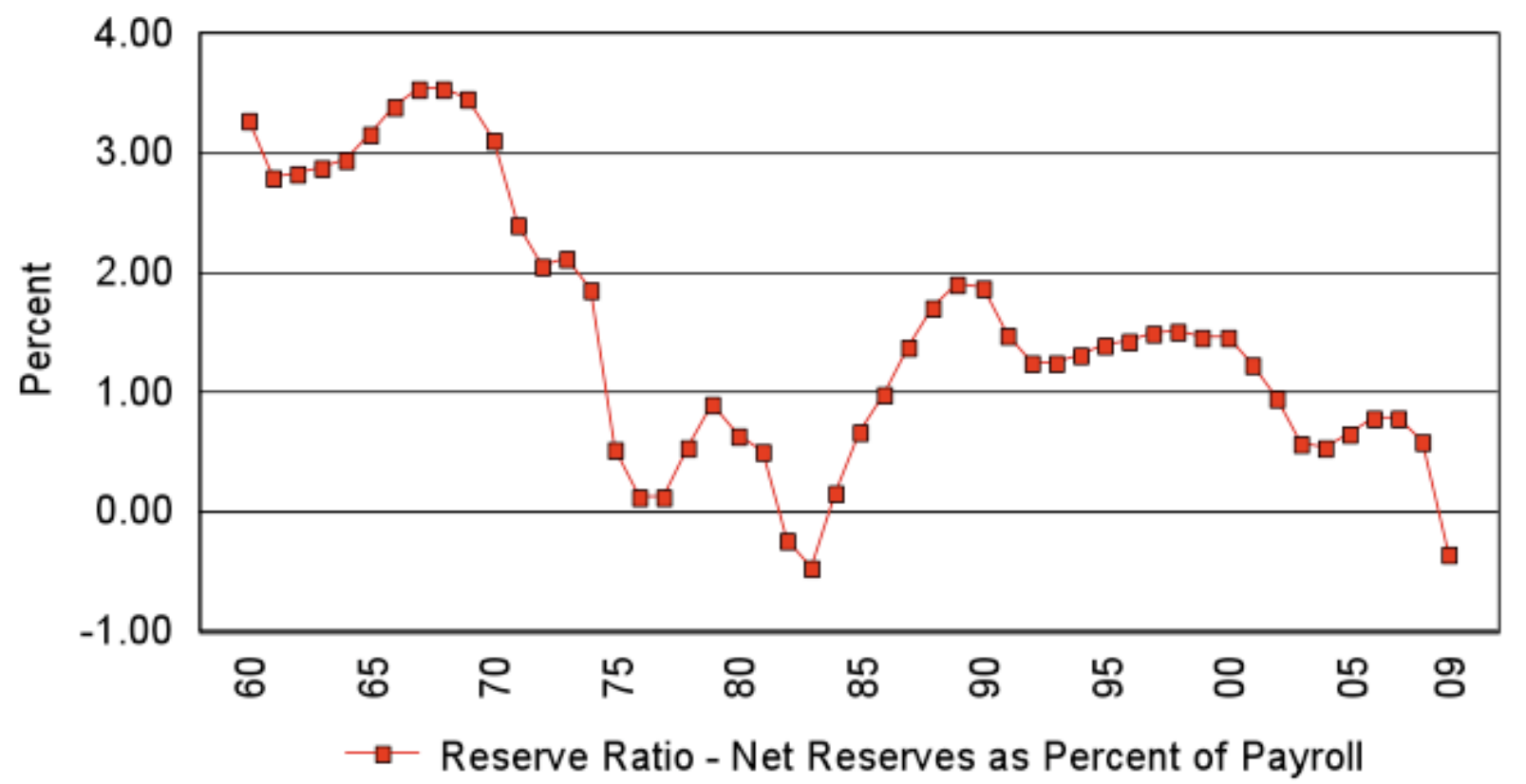

Source: Vroman (2010), from U.S. Department of Labor (various issues).

States differ greatly in their trust fund solvency, and Vroman suggested that indexing the wage base to the state average weekly wage is the key to maintaining a solvent UI trust fund. Sixteen states have indexed their wage base, and the average taxable wage base in these sixteen states is just over $\$ 27,000$. In the 35 states that do not index the wage base, the average is just $\$ 9,700$. The consequences of these differences are clear: At the onset of the 2008 recession, the states that indexed their wage base had reserve ratios averaging just short of 2 (that is, their trust fund reserves were nearly 2 percent of total annual wages paid in the state). The states that did not index had reserve ratios averaging less than 0.5 .

The correlation between indexing the taxable wage base and solvency is striking. Of the 16 states that index, only 5 (31 percent) have had to borrow from the federal government; of the 35 that do not index, 29 (83 percent) have had to borrow. 
Vroman suggested that the long-term solution to the problem of UI solvency is for the federal government to mandate a higher taxable wage base. Indeed, Vroman suggested that the taxable wage base be raised to $\$ 100,000$ — nearly twice the level suggested by Gary Burtless in the previous panel.

\section{Rich Hobbie}

Hobbie addressed the link between solvency and the effectiveness of UI as an automatic stabilizer. He made four main points:

- State UI programs are powerful automatic stabilizers for the economy when they are forward funded, as intended.

- Moving away from forward funding toward a borrow-and-repay approach tends to lessen the UI system's automatic stabilization effects.

- This point can be illustrated by comparing the pattern of tax collections under forward funding with the pattern under a simulated borrow-and-repay approach.

- The results suggest that taxes increase more sharply after a recession under the borrowand-repay approach than with forward funding.

Hobbie illustrated the automatic stabilizing effects of UI under forward funding using the accompanying Figure 3. The darker time series is the "benefit cost rate," or regular state benefits paid to claimants divided by total annual wages earned by covered workers, expressed in percentage terms. (Note that the benefit cost rate does not consider extended or emergency benefits.) It shows, for example, that UI recipients received benefits amounting to about 1 percent of total wages during the years following the recession of 2001.

The lighter time series is the "average tax rate," or UI payroll tax revenues again divided by wages, again in percentage terms. It shows that UI payroll taxes have not exceeded 1 percent of wages since the late 1980 s. 
Figure 3.

Average UI Benefit Cost Rate and Average UI Payroll Tax Rate, 1938-2008

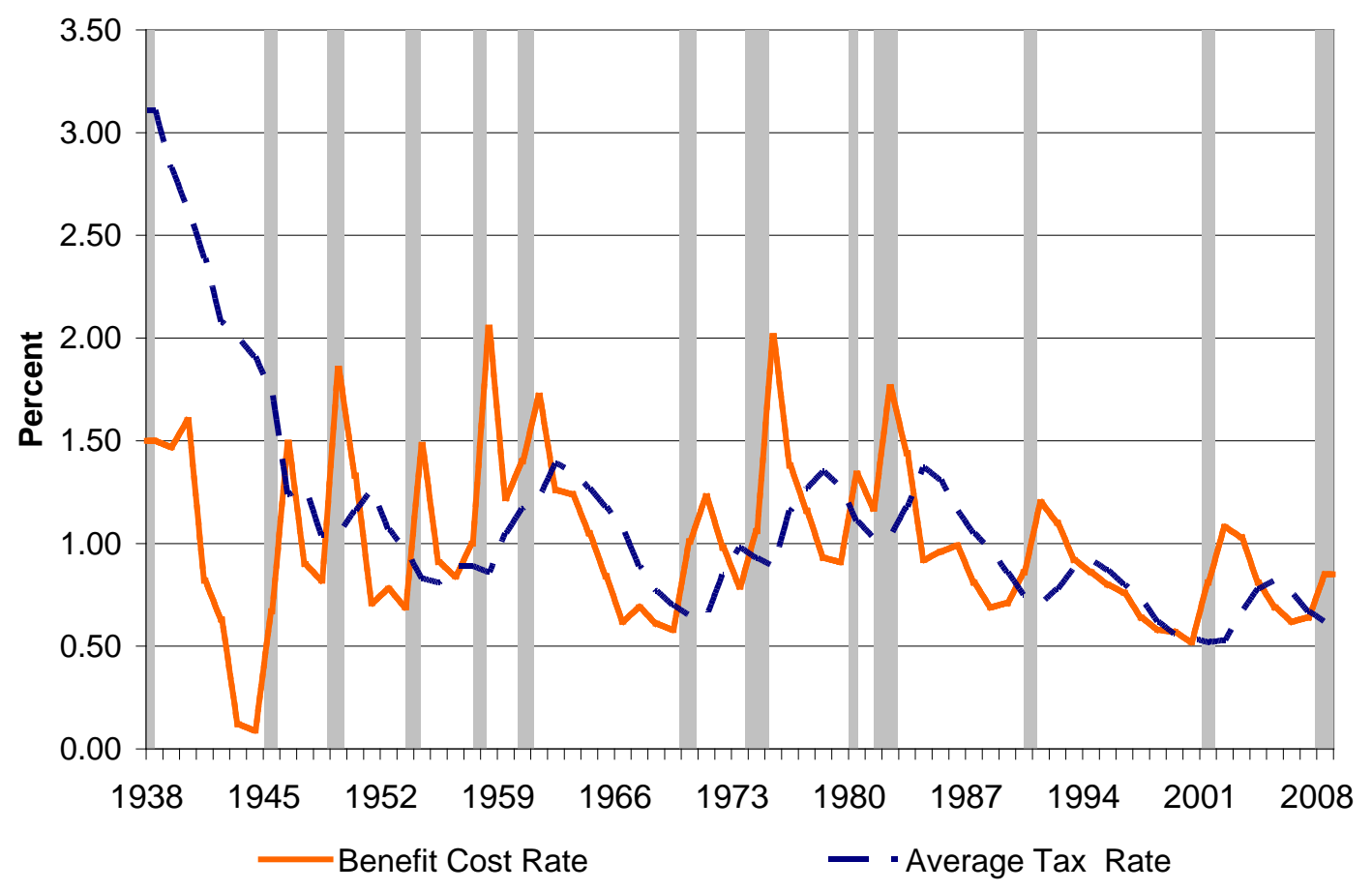

Note: Recession periods indicated by shading.

Sources: Hobbie (2010), from U.S. Department of Labor, Unemployment Insurance Data Summary (various issues) and National Bureau of Economic Research, "U.S. Business Cycle Expansions and Contractions."

Figure 3 shows that the benefit cost rate exceeds the average tax rate during recessions, drawing down trust fund reserves and in effect injecting income for consumption into the economy. During periods of recovery, the opposite is true: taxes exceed benefits, restraining the economy and replenishing state UI trust funds. The result resembles a cyclical pattern of saving and dissaving. Forward funding makes UI an automatic stabilizer.

Hobbie's concern is that some states have pursued a policy of maintaining low reserves even in good times with the expectation of borrowing to cover benefits during a recession - a borrowand-repay approach. Hobbie argues that this reduces the countercyclical stabilizing effects of the UI system. He illustrates this in two steps. First, he asks what pattern of tax collections would result from a policy that always borrowed to cover UI costs in year $t$, then taxed employers to repay the loans in year $t+1$. The answer is simply the benefit cost rate shifted forward by one year because whatever is paid in year $t$ was borrowed and must be repaid in year $t+1$. Second, he compares this hypothetical pattern of tax collections with the pattern of tax collections actually observed over the last 70 years (that is, the average tax rate). 
The result of this exercise is shown in Figure 4, which displays the benefit cost rate shifted forward by one year (the hypothetical pattern under a borrow-and-repay strategy) and the actual average tax rate (a pattern resembling that under forward funding) ${ }^{21}$. The figure shows that, under the borrow-and-repay approach, the taxes collected from employers increase sharply immediately following recessions, whereas under an approach closer to forward funding, the tax increases are delayed until the recovery has established itself. Accordingly, the borrow-and-pay approach puts a substantial drag on the economy just as it is emerging from a recession, rather than delaying the restraining effects of the UI payroll tax. The conclusion is that the borrow-andpay approach undermines the countercyclical stimulus provided by the UI system.

Figure 4.

Average UI Benefit Cost Rate (Shifted by One Year) and Average UI Payroll Tax Rate, 1938-2008

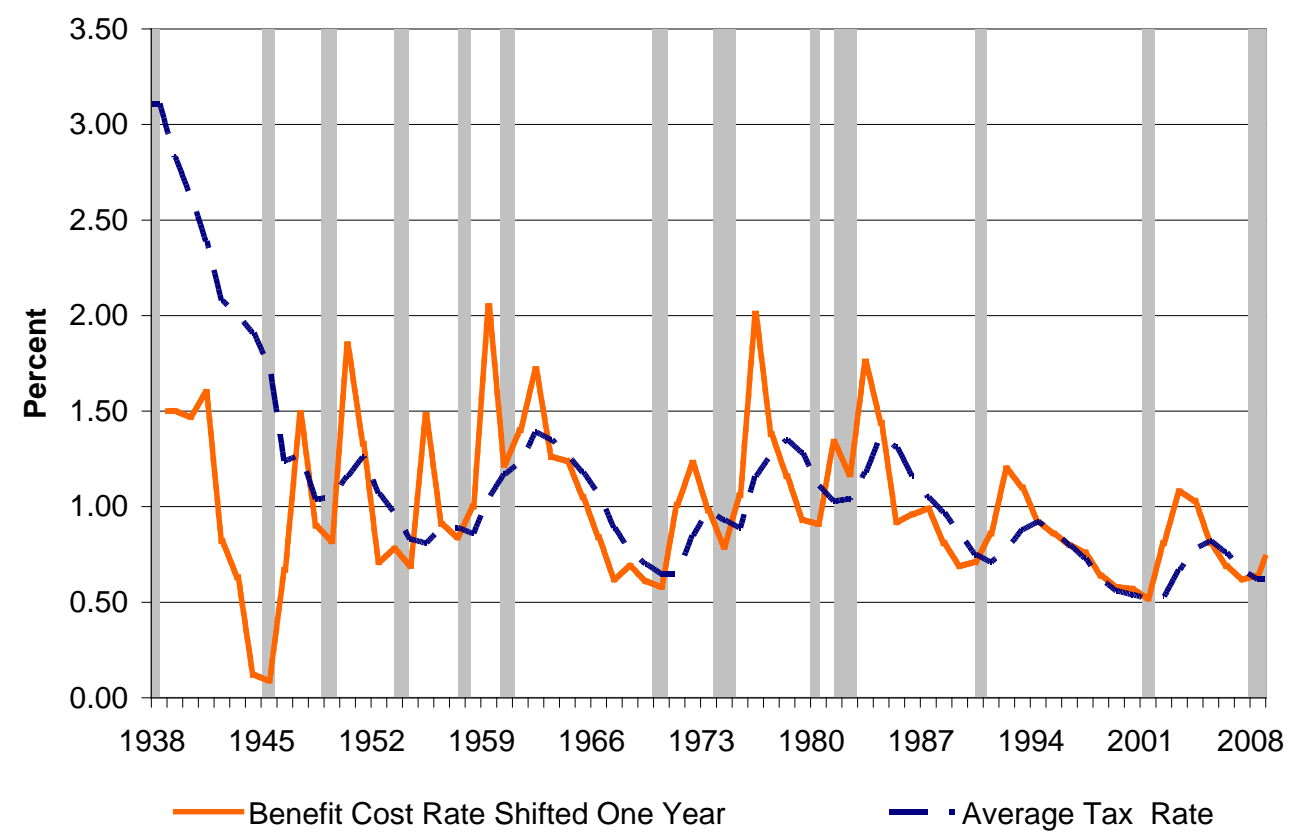

Note: Recession periods indicated by shading.

Sources: Hobbie (2010), from U.S. Department of Labor, Unemployment Insurance Data Summary (various issues) and National Bureau of Economic Research, "U.S. Business Cycle Expansions and Contractions."

${ }^{21}$ The actual history of the average tax rate is in fact a mixture of forward funding (in the states that do forward fund) and borrow-and-pay (in the states that do not forward fund). 


\section{Discussion}

Ralph Smith asked about strategies for raising the UI taxable wage base and whether other policies are available to improve trust fund solvency. Wayne Vroman responded that one strategy might be for the federal government to ease a state's burden of repaying its loans if that state raised or indexed its taxable wage base. The idea would be to allow insolvent states to raise their wage bases slowly and avoid hitting employers with large, sudden UI tax increases. In any case, Vroman believes that federal leadership is needed because insolvent states are unlikely to act on their own, and it will take many years for the trust funds of insolvent states to return to a good position.

Rich Hobbie agreed that incentives will be needed to induce states to raise their wage bases. The federal government has suspended interest on loans to the states from February 2009 through December 2010, and this suspension could be extended if a state agreed to raise its wage base. He also noted that, under certain conditions, the federal tax rate on employers in a debtor state eventually rises if a state fails to repay its loan. Relaxing this increase might be another incentive for states to raise their wage bases. He remarked that, following the double-dip recessions of the early 1980s, it was eight years before all states had repaid their federal loans, and he believes it will take even longer following this recession. Policymakers should be careful not to raise taxes too much early in the recovery.

Douglas Holmes remarked that, with regard to the taxable wage base, each state is likely to have different preferences depending on the mix of employers in the state. For example, although it is an oversimplification, industries that face high UI tax rates tend to prefer a smaller tax base, and those that face low UI tax rates tend to prefer a larger base. So the political discussion is likely to be different in each state. Also, employers in states with a small tax base would probably view an increase in the federal base as punishment for insolvency and for borrowing from the federal government unless provisions were made to repay debts over time.

Holmes also cautioned about inferring that an indexed wage base causes UI trust fund solvency. It also seems possible that volatile industries - manufacturing and construction, for example are overrepresented in large states. If so, then the tendency of UI trust funds in large states to be insolvent could be due to volatility of employment as well as to low wage bases.

Matt Weidinger (House Ways and Means Committee) asked about the possibility of the federal government forgiving part of the debt incurred by some large states. This question set off a lengthy discussion. Vroman started by saying that some states expected debt forgiveness following the recessions of the mid 1970s and early 1980s, but it didn't happen. He believes it would be a mistake to allow debt forgiveness because it would create a moral hazard problem: States would expect the federal government to bail them out, they would have no incentive to maintain a solvent trust fund, and the system would break down. So although it is reasonable to negotiate terms of repayment (for example, allowing a state additional time to repay), ultimately the debt obligations need to be honored.

Rick McHugh (National Employment Law Project) disagreed with Vroman and said that "some sort of partial debt forgiveness by the federal government is going to have to be on the table" in order to avoid benefit reductions in some large states like Michigan, California, and Ohio. 
Laura Boyett (Director of UI in the State of Maine) remarked that Maine's wage base is not indexed, but Maine assigns tax rates using a so-called array allocation approach in which tax rates are tied to the average wage level. It has worked well to keep Maine's trust fund solvent. However, it was politically difficult to achieve, and her department faced resistance and pressure to drop the standards it was trying to adopt in order to keep the trust fund solvent. She expressed the hope that something will be done to induce other states to make a similar commitment to solvency.

Ray Mulvaney (Administrator of the Montana Department of Labor and Industry) said that Montana's experience was similar to Maine's. Montana's trust fund was insolvent after the recessions of the mid 1970s and early 1980s, so in 1983, the state indexed its taxable wage base and adopted array allocation to assign tax rates. Since then, Montana's UI trust fund has been solvent. But Mulvaney suggested that for the federal government to forgive the debts of some large states would raise a fairness issue and could erode support for Montana's UI program in the employer community.

Andrew Sherrill (U.S. Government Accountability Office) stated that a recent GAO study on financing UI reported findings consistent with the experiences described by Boyett and Mulvaney. Like them, many state UI administrators face political obstacles to raising the taxable wage base. In light of that, the GAO suggested the most straightforward way to solve the UI funding problem would be for the federal government to raise and index the federal taxable wage base, and to require the states to set a taxable wage base at least as high as the federal base. 


\section{Panel 6: Getting Workers Back to Work}

Moderator: Roberta Gassman

Secretary, Wisconsin Department of Workforce Development

\section{Bill Warren}

Executive Director, DirectEmployers Association

\section{Dan Black}

Professor and Deputy Dean, Harris School, University of Chicago

\section{Christopher O’Leary}

Senior Economist, W.E. Upjohn Institute

Reemployment is an essential goal of UI and related programs under the Workforce Investment Act. UI is predicated on the assumption that its recipients are able and available to work. UI and the public labor exchange authorized under the Wagner-Peyser Act have been viewed as complementary programs from their beginnings, although the degree to which they have been coordinated has varied over time and across states.

During a recession the number of job vacancies falls, and it is reasonable to ask whether the role of reemployment policy should adapt to a slack labor market, and if so, how. States sometimes suspend UI work search requirements during recessions when they have evidence that job openings are so scarce that job search is likely to be futile. Should UI and reemployment policies adjust in other ways as well?

\section{Roberta Gassman}

Secretary Gassman discussed the importance of reemployment services and pointed to evidence provided by Wisconsin's demonstration project on "Strengthening Connections between UI and One-Stop Delivery Systems,” conducted during 2004-2006. This demonstration was a response to concerns that UI claimants' use of One-Stop Centers and reemployment services has declined because UI claims are now filed by telephone and through the internet. As in-person claiming has given way to telephone and internet claims, both the average duration of UI benefit receipt and the percentage of UI recipients who exhaust their benefits have increased. The goal of the Wisconsin demonstration was to learn whether the relationship was causal.

The Wisconsin demonstration was conducted at three One-Stop centers - one in Oshkosh and two in Milwaukee. In these regions, the UI and One-Stop computer systems were integrated, UI staff assisted in the reemployment orientation sessions conducted at the Job Centers, and working relationships between UI adjudicators and One-Stop Center staff were encouraged. Also, individual UI claimants were automatically registered for work, and an expanded pool of workers were referred to enhanced reemployment services, of the kind usually given only to workers expected to experience long spells of unemployment under the Worker Profiling and Reemployment Services program. 
Findings from the demonstration suggest that workers in the demonstration group experienced shorter spells of UI benefit receipt (by about 0.6 week on average) and somewhat higher earnings after reemployment (by about $\$ 200$ per quarter) than workers in a matched comparison group. These findings are similar to those from other demonstrations and experiments examining the effects of intensive reemployment services, and they suggest the importance of directing workers to those services.

Secretary Gassman noted that the Recovery Act included funding for reemployment services, and that this is a positive development because it had allowed her department to hire additional staff and increase the number of reemployment service sessions from 2 to 90 per week.

Finally, Secretary Gassman remarked on the importance she attaches to skills testing and credentials. Wisconsin has used ACT's WorkKeys assessments to test for skills in applied math, reading, and locating information. These assessments can lead to a National Career Readiness Certificate at one of four levels, and Wisconsin has used Recovery Act funds to pay for workers to take the WorkKeys assessments so they can earn a certificate.

\section{Bill Warren}

Warren described the DirectEmployers’ Association, a non-profit association of more than 500 leading U.S. companies:

- DirectEmployers Association's mission is “to provide employers with an internet-based employment network that is cost-effective, improves labor market efficiency, and reaches an ethnically diverse national and international workforce."

- DirectEmployers Association is allied with the National Association of State Workforce Agencies (NASWA), the National Association of Colleges and Employers (NACE), and American Association of Community Colleges (AACC).

- Its services include the JobCentral National Labor Exchange, a job bank that has contacts with nearly all state job banks and many corporate career sites.

- Job seekers can access JobCentral at no charge - after creating an account, they can post their resume and browse jobs based on numerous criteria.

DirectEmployers Association is a 501(c)(6) association of about 550 employers, mainly Fortune 1000 companies. It has a board of directors of 17 people representing companies like IBM, KPMG, Xerox, and General Dynamics. Many of its members are federal contractors. It works with state workforce agencies to reduce the cost of matching workers to job vacancies, offers affirmative action compliance, and provides employers with access to veterans, minorities, women, seniors, and disabled workers. 
DirectEmployers' key alliance is with National Association of State Workforce Agencies (NASWA). When the U.S. Department of Labor ended its support for America's Job Bank (AJB) in June 2007, NASWA and private employers were looking for a national internet-based job bank to replace it. AJB was discontinued in part because it was an antiquated and costly system. DirectEmployers Association was formed, went through a nine- to ten-month evaluation of AJB with NASWA, and was selected to create a new national job bank, the JobCentral National Labor Exchange.

In addition to its alliance with NASWA, DirectEmployers Association is allied with the National Association of Colleges and Employers (NACE) and the American Association of Community Colleges (AACC). DirectEmployers manages the state job banks of five states and has contracts with 48 of 50 states and DC. Through the JobCentral National Labor Exchange, DirectEmployers downloads listings of job seekers from 30 state job banks and uploads listings of job vacancies to 41 state job banks. Even more states would be served except that some states have antiquated technologies that create technical problems. Still, the number of states served is increasing.

Job seekers can access JobCentral at no charge. After creating an account, a job seeker can post his or her resume and browse jobs by occupation, state, metro area, industry, and company. They can also access international jobs and search for career events. By inserting ".jobs" at the end of a URL, job seekers can quickly locate an employer's career site with a direct connection (for example, www.allstate.jobs, or www.homedepot.jobs). Displaced workers who identify their previous employer can find similar positions if the employer has entered information about that position; this serves as a job matching service to displaced workers at no cost.

DirectEmployers' member companies provide these services at no charge both to reduce the costs of filling vacancies and as a way of handling compliance with federal contract and affirmative action programs. JobCentral National Labor Exchange provides a pipeline to veterans, minorities, women, senior workers, and disabled workers.

Direct Employers Association provides a range of services to its members, including free access to JobCentral National Labor Exchange, numerous information services, and opportunities for networking. Non-member companies also have access to JobCentral National Labor Exchange at nominal cost.

\section{Dan Black}

Black's presentation centered on labor supply effects of UI and the appropriate policy response during a recession:

- We know that UI creates a disincentive to search for and accept reemployment.

- Therefore, when jobs are available, UI recipients should be monitored to ensure that they are really looking for work. 
- But if job vacancies are scarce, it may be that supply-side efforts to push workers to accept reemployment reduce workers' well-being without any offsetting social benefit.

- The correct policy response is not obvious and may differ for workers in different occupations or with different job tenures.

Economic theory suggests, and empirical evidence has shown convincingly, that UI creates a disincentive for recipients to search for work and accept a new job. This moral hazard of UI can be checked in two ways - by offering only partial coverage for UI recipients' earnings losses and by monitoring their job search efforts.

Although it makes sense to monitor job search effort in normal times, Black questioned whether it makes sense to do so during a recession, when the likelihood of reemployment is relatively low because a greater number of unemployed job seekers are pursuing fewer job vacancies. He relied on evidence from the Kentucky Profiling and Reemployment Services Experiment (Black, Smith, Berger, and Noel 2003) to show that monitoring job search, and even attempting to provide reemployment services, may be inefficient during a recession.

The Kentucky experiment was designed so that a group of workers assigned to reemployment services could be compared with a control group. Black and his coauthors estimated that the workers assigned to reemployment services received UI benefits for 2 weeks less than the controls. But looking at the patterns of exit from UI receipt made it clear that most of that reduction occurred because the workers assigned to reemployment services ended their UI claim before they ever attended the job search workshops.

The goal of intensive job search assistance, of course, is to give workers the skills and tools they need to search for a job effectively. But the Kentucky experiment (along with several earlier job search assistance experiments) suggests that at least part of the effect of job search assistance comes by way of a "threat effect" - that is, rather than attend job search workshops they see as onerous, some workers end their UI claim (perhaps after finding a job, but perhaps not). The cost to these workers of receiving reemployment services outweighs the benefits, which include UI benefits.

The point is that monitoring job search, even in the guise of reemployment services, may have few social benefits when jobs vacancies are scarce, and it is costly to the workforce agency. As a result, it is not clear that enforcing the work search test or requiring workers to receive reemployment services during a recession makes sense. It may well be that vocational training or some other form of human capital investment is appropriate for certain workers - especially younger workers who will have many years over which to earn a return on the investment. For other workers, though, it may be appropriate to relax the work test and allow receipt of benefits without requiring job search. 


\section{Christopher O’Leary}

O’Leary's presentation touched on a wide range of reemployment strategies and focused on the following points:

- Reemployment programs are an essential part of UI.

- But gaining reemployment is more difficult during a recession than in normal times, so it may be necessary to adjust the focus of reemployment policy.

- In particular, labor supply strategies for reemployment - like enforcement of the work test, eligibility review interviews, and reemployment bonuses — may be less successful in a recession than in normal times.

- Labor demand strategies — work sharing, wage insurance, and wage-bill subsidies — are more likely to succeed in a weak labor market.

Encouraging reemployment has been part of UI from the beginning of the program, although it is important to consider how strongly the work test should be enforced during a deep recession. During this recession, the average duration of benefit receipt has risen sharply, and the UI exhaustion rate of regular benefits has increased from about 33 percent to 55 percent. This is bad news, of course, but the good news is that not all UI recipients are exhausting their regular benefits, which suggests that some jobs are available.

O’Leary noted that unemployment is insurable only for a worker who has substantial attachment to the work force, separated from his or her job involuntarily, and is able, available, and actively seeking work. The short-term goals of reemployment policy, then, are to shorten workers' spells on UI and to reduce UI payouts. The longer-term goals are to increase employment and income stability, improve earnings (and hence tax contributions), and reduce reliance on social assistance. The immediate benefit of reemployment policy to the UI system is reduced benefit payments - a one-week reduction in the average duration of UI spells in 2009 would have saved the system roughly $\$ 4.3$ billion.

O’Leary briefly reviewed the labor supply strategies for reemployment. These include enforcing the UI work test, targeted reemployment services (under Worker Profiling and Reemployment Services), eligibility review interviews, reemployment eligibility assessments, commissionerapproved training, Trade Adjustment Assistance, reemployment bonuses, and personal reemployment accounts. (See O’Leary 2010 for a review of evidence on the effectiveness of both supply and demand strategies for reemployment.) A serious concern is that labor supply strategies are effective only when there is sufficient demand for labor. Labor supply approaches are less likely to be effective during a recession than during a period of recovery.

O’Leary then briefly reviewed labor demand strategies. These include short-time compensation (or work sharing UI, available in 17 states), self-employment assistance (available in 7 states), wage subsidies to employers, and wage insurance (including wage supplements paid to workers and partial UI benefits). He focused mainly on the last two approaches, and noted that the 
evidence on wage subsidies to employers has not been encouraging. In particular, employers appear to view workers who would be subsidized as "damaged goods" and avoid hiring them. In contrast, wage insurance, which pays a subsidy to a worker, avoids this stigma effect because the employer is unaware that the worker is receiving a wage supplement. In fact, wage insurance works on both the supply and demand sides of the labor market. Workers know they will receive an earnings supplement, so they lower their reservation wage and accept a job they might otherwise reject. Employers find that workers are willing to work for reduced wages, so they hire more than otherwise.

O’Leary suggested that partial UI benefits offer a possible way to implement a wage supplement or wage insurance. A demonstration in Washington State has shown that a generous earnings disregard encourages workers to take part-time employment or a job paying a lower wage than previously earned (O’Leary 1997). Such a program acts like wage insurance, supplementing a relatively low wage with UI benefits. The outcome is good for both workers and employers: Workers become reemployed so they maintain their skills, and employers are able to hire workers at a lower wage than otherwise because UI benefits top up what the employer pays them. ${ }^{22}$

\section{Discussion}

Roberta Gassman opened by noting again the difficulty of getting workers back to work in a recession. Wisconsin currently has about 24,000 job listings, compared with about 160,000 UI recipients. She believes it is valuable for unemployed workers to visit job centers, have their skills assessed, and get connected to counseling and perhaps training, so they will be better prepared when the labor market improves. Nevertheless, the Wisconsin Department of Workforce Development has concerns about requiring UI recipients to engage in job search during such a deep recession, and she asked for comments.

Chris O'Leary remarked that one way of handling the work test, used by some states, is to change the wage requirement for suitable work as a worker's unemployment duration increases. Whereas rejecting a job paying \$10 per hour as unsuitable would be acceptable early in an unemployment spell, it might not be acceptable later. He also noted that the Job Openings and Labor Turnover Survey (JOLTS) data show that, even though the job opening rate fell from about 3.3 percent in mid 2007 to 2.2 percent in mid 2010, job openings do exist, and over onethird of all jobs have been turning over annually, even during the recession (based on the current monthly hire rate of 3.3 percent). So opportunities do exist for UI recipients to become reemployed.

Till von Wachter remarked that an alternative to wage insurance would be to expand short-time compensation (or work-sharing UI) and pay benefits before workers are laid off. This would

\footnotetext{
${ }^{22}$ Many in organized labor oppose wage insurance because it would encourage workers to accept jobs at lower wages than they otherwise might, and hence could undermine wage levels. Many labor economists favor wage insurance because, by encouraging workers to accept lower-wage jobs, they would become reemployed more quickly and thereby avoid depreciation of their skills.
} 
avoid the immense cost that people suffer when they are laid off. Those costs are not avoided with wage insurance. Another possible benefit is that short-time compensation may smooth layoffs over a longer time period and spread them out, so they are less likely to occur during a recession, when job openings are scarcer.

Erica Groshen asked whether any programs consider worker mobility and the fact that many workers need to move in order to obtain a good job opportunity. Geographic mobility has been very low recently, probably due to the bad housing market. Have policymakers been discussing this problem? Dan Black replied that the anecdotal evidence suggests that low mobility and the bad housing market are important issues. But for political reasons, they are difficult problems to address. Whenever a relocation program is discussed, members of Congress from declining districts oppose it because they don't want to subsidize people to leave their district. Detroit may need to shrink, but no Michigan politician would advocate relocating Michigan residents to other states. Another participant mentioned that the New Jersey UI Reemployment Demonstration (Corson et al. 1989) included a treatment that offered information about relocation assistance, but the treatment had little or no effect.

Gay Gilbert asked whether it is realistic to expect reemployment policy always to reduce unemployment duration, especially given the apparent increase in structural unemployment. For example, the intended benefits of training are long-term - training does not get workers back to work quickly. So it is important not to define the benefits of reemployment policy too narrowly.

Douglas Holmes commented that it would be useful to know what happens to long-term unemployed workers and to track the programs and strategies that work for them. Research studying the occupations and industries they move to, and what role workforce development plays, would be helpful in planning. Roberta Gassman agreed that this is an important suggestion for future research. 


\section{An Agenda for Research}

As Gay Gilbert noted during the roundtable, creating a balanced UI policy will require the participation and cooperation of all interested parties - representatives of employers and workers, and UI administrators - and should be informed by the best available research. Accordingly, one goal of the roundtable was to generate an agenda for future research on UI. The roundtable offered an excellent opportunity to create such an agenda because, during the day, a number of questions came up that could not be answered based on existing research. Following is a brief discussion of those questions and the research topics they suggest.

1. The method of funding UI administration was discussed extensively during Panel 1. In particular, UI administration competes for funding with all other domestic discretionary programs, despite the existence of FUTA revenues collected for UI administration and related purposes. What are the impacts of the existing funding structure on program outcomes? What are the alternatives to the existing structure, and how would alternative approaches to funding change program outcomes? What is the best method of allocating funds for UI administration to the states? (See Gay Gilbert’s remarks during Panel 1.)

2. The declining performance of UI administration — as estimated by timeliness of payments, the disposition of appeals, and other performance measures - has long been a concern, and difficulties during the Great Recession have heightened those concerns. What is the relationship between funding for UI administration and performance of the system? How could performance of the system be improved, given the existing administrative structure? (See comments during Panel 1 by Gay Gilbert and Margaret Simms.)

3. Under UI Modernization, many states have changed nonmonetary eligibility requirements for UI, making it easier for many workers who previously would have been denied benefits to qualify. Have the changes in eligibility requirements had their intended effects? What are the characteristics of workers who now qualify but would have been denied in the past? How many workers have been affected by the changes encouraged by UI Modernization? What are the financial implications of changes in eligibility requirements? (See the discussion during Panel 3.)

4. It is well known that the UI recipiency rate varies significantly across the states and that many workers who are eligible for benefits do not claim them. UI recipiency has been the subject of past research because the program's effectiveness in smoothing consumption and stabilizing the macroeconomy depends on a high rate of participation, but answers to questions about recipiency have been elusive. What are the determinants of UI recipiency at the state level? Why has the UI recipiency rate trended down over time? What factors contribute to eligible workers not claiming benefits? Would outreach programs, especially to low-wage workers, be effective in boosting UI recipiency? (See the discussion during Panel 3.)

5. Since the overhaul of welfare in 1996, cash assistance has declined as a source of income for single-parent households. As a result, and by design, these households now depend more on the labor market and earnings to meet their consumption needs. When a single 
parent loses her job, the household loses not just earnings - it may also lose employerprovided health insurance, income from the Earned Income Tax Credit, and support for childcare. What happens to the consumption level of a single-parent household when the parent loses her job? Is UI adequate to compensate for the losses in earnings and other earning-related support? Moreover, what is the effect of job loss on the well-being of children in a single-parent household? To what extent does the dependents' allowance help close the consumption gap created by unemployment in a single-parent household? (See the discussion during Panel 3.)

6. A recent National Urban League report concluded, "Unemployed blacks are more likely to be excluded from unemployment benefits than their white counterparts, [and] restrictive state unemployment eligibility rules disproportionately exclude blacks” (National Urban League 2010). What factors contribute to the lower percentage of unemployed blacks than of unemployed whites receiving UI benefits? What could be done to address the issue? Are there inequities among groups of UI claimants that could be addressed? (See the Panel 3 discussion.)

7. Dissatisfaction with the existing extended benefits programs is widespread. Although the standby EB program is relatively straightforward to administer (because it is a standing program), EB triggers have been changed over the years so as to make the program less likely to be triggered. As a result, EB rarely triggered on during the recessions of 19901991 and 2001, and many observers believe the program has become ineffective. Even when EB has triggered on, as in the current recession, it has been perceived as inadequate, and Congress has stepped in with emergency extended benefits like EUC-08. But emergency benefit programs have been confusing to claimants, as well as difficult and costly to administer because they must be implemented quickly and are changed frequently. How could an adequate and effective extended benefits program be structured? What are the goals such a program would need to meet, and what combination of triggers and UI durations would satisfy those goals? Should such a program be funded entirely by the federal government, or should funding be shared by the federal government and the states? (See the discussion during Panel 3.)

8. In structuring extended benefits and other programs for the long-term unemployed, it would be useful to know what happens to long-term unemployed workers. For example, how many leave the labor force, and how many become reemployed? Among those who find a new job, what strategies and programs work for them, and what role does workforce development play in their reemployment? To what occupations and industries do they move? How do those who leave the labor force support themselves? Are there systematic differences between those who leave the labor force and those who find a new job, and could an understanding of these differences help in directing reemployment services to those most likely to take advantage of them? (See comments by Doug Holmes at the end of the Panel 3 discussion.)

9. Panel 4 included an extended (and impromptu) discussion of the burden of the UI payroll tax. Although the payroll tax is collected from employers, economists generally assume (and some research has suggested) that most of the tax is ultimately paid for by workers in the form of lower wages and salaries. The roundtable discussion suggested skepticism about the conclusions economists have reached, and some important qualifications to 
those conclusions may be necessary. Who bears the burden of the UI payroll tax and why? Does the burden of the payroll tax vary across industry or type of employer? What would be the effects, if any, of collecting part of the UI payroll tax directly from workers? (See the discussion during Panel 4.)

10. During Panel 4, Patricia Anderson raised a central problem that arises from incomplete experience rating of the UI payroll tax. Specifically, stable employers and industries subsidize the UI benefits of workers laid off from unstable employers and industries, and these inter-employer and inter-industry cross-subsidies persist over many years. How can the inequities and inefficiencies created by the incomplete experience rating be reduced without destroying the insurance character of UI? (See the discussion during Panel 4.)

11. Macroeconomic textbooks accept as an article of faith that UI provides countercyclical stimulus, and several roundtable participants discussed the countercyclical effects of UI. But little research has examined whether the countercyclical effectiveness of UI differs under different methods of funding, especially forward funding versus borrow-and-repay. Rich Hobbie in particular emphasized the importance of forward funding to UI's countercyclical effectiveness. What are the macroeconomic effects of UI and extended benefits, and how do those effects differ under different methods of funding, especially forward funding versus borrow-and-repay? What are the effects of UI and extended benefits on consumption smoothing? (See the comments by Rich Hobbie and Andrew Stettner during Panel 5.)

12. Wayne Vroman presented evidence suggesting that, when a state indexes its taxable wage base, its trust fund is less likely to become depleted. Doug Holmes questioned whether this relationship is causal, and suggested that other factors could also contribute to insolvency - large manufacturing, agriculture, and construction sectors, or large urban areas, for example. It would be useful to gain a more complete understanding of the factors contributing to state trust fund insolvency. (See the exchange between Doug Holmes and Wayne Vroman during the Panel 5 discussion.)

13. The perceived need for additional reemployment services came up repeatedly during the roundtable. Although much research on the impacts of reemployment services already exists, it remains unclear whether the states would know how to use additional funds effectively if they were available. Which reemployment services are most effective? How does the effectiveness of various reemployment services vary over the business cycle? How should services be directed — that is, which services are most effective with different kinds of workers? Which services are best suited to a worker given his or her age, education, earnings history, former occupation, and job tenure? (See the discussions during Panels 1 and 6.) 


\section{References}

Advisory Council on Unemployment Compensation, Report and Recommendations. Washington, DC: Advisory Council on Unemployment Compensation, 1994 (February).

Advisory Council on Unemployment Compensation, Unemployment Insurance in the United States: Benefits, Financing, and Coverage. Washington, DC: Advisory Council on Unemployment Compensation, 1995 (February).

Advisory Council on Unemployment Compensation, Background Papers, Volumes I, II, III, and IV. Washington, DC: Advisory Council on Unemployment Compensation, 1995 (July) and 1996 (January).

Advisory Council on Unemployment Compensation, Defining Federal and State Roles in Unemployment Insurance. Washington, DC: Advisory Council on Unemployment Compensation, 1996 (January).

Advisory Council on Unemployment Compensation, Collected Findings and Recommendations: 1994-1996. Washington, DC: Advisory Council on Unemployment Compensation, 1996.

Anderson, Patricia M., “The Unemployment Insurance Payroll Tax.” National Academy of Social Insurance Policy Brief, August 2010.

Anderson, Patricia and Bruce Meyer, "Unemployment Insurance Tax Burdens and Benefits: Funding Family Leave and Reforming the Payroll Tax.” National Tax Journal 61 (2006): 77-95.

Bassi, Laurie J. and Stephen A. Woodbury, editors, Reform of the Unemployment Insurance System. Stamford, CT: JAI Press, 1998.

Bassi, Laurie J. and Stephen A. Woodbury, editors, Long-Term Unemployment and Reemployment Policy. Stamford, CT: JAI Press, 2000.

Black, Dan A., Jeffrey A. Smith, Mark C. Berger, and Brett J. Noel, "Is the Threat of Reemployment Services More Effective Than the Services Themselves? Evidence from Random Assignment in the UI System.” American Economic Review 93 (2003): 1313-1327.

Blaustein, Saul, Unemployment Insurance in the United States. Kalamazoo, MI: W.E. Upjohn Institute, 1993.

Chocolaad, Yvette, "Results of a Survey of State Workforce Administrators on Early Implementation of the Workforce Provisions of the Recovery Act.” Washington, DC: Center for Employment Security Education and Research (CESER), National Association of State Workforce Agencies (NASWA), May 4, 2010.

Corson, Walter, Paul T. Decker, Shari Miller Dunstan, and Anne R. Gordon. “The New Jersey Unemployment Insurance Reemployment Demonstration Project: Final Evaluation Report.” Unemployment Insurance Occasional Paper 89-03. Washington, DC: Employment and Training Administration, U.S. Department of Labor, April 1989. 
Eberts, Randall W. and Christopher J. O’Leary, “A Frontline Decision Support System for Georgia Career Centers.” Kalamazoo, MI: W.E. Upjohn Institute Working Paper No. 02-84, July 2002.

Feldstein, Martin, “The Effect of Unemployment Insurance on Temporary Layoff Unemployment.” American Economic Review 68 (December 1978): 834-846.

Fendler, Ben, "Unemployment Insurance Provisions of the Recovery Act Survey: Summary of State Responses.” Washington, DC: Center for Employment Security Education and Research (CESER), National Association of State Workforce Agencies (NASWA), May 4, 2010.

Hamermesh, Daniel S., Jobless Pay and the Economy. Baltimore, MD: Johns Hopkins University Press, 1972.

Hobbie, Richard A. with assistance from Ben Fendler and Charles Terrell, "Solvency of Unemployment Insurance: Effectiveness as an Automatic Stabilizer.” Presentation to the National Academy of Social Insurance Unemployment Insurance Roundtable, Washington, DC, July 13, 2010.

Jacobson, Louis S., "Strengthening One-Stop Career Centers: Helping More Unemployed Workers Find Jobs and Build Skills.” The Brookings Institution/Hamilton Project Discussion Paper 2009-01, April 2009.

Karni, Edi, “Optimal Unemployment Insurance: A Survey.” Southern Economic Journal 66 (October 1999): 442-465.

Mankiw, N. Gregory, Principles of Economics, third edition. Mason, OH: Thompson South-Western, 2004.

National Bureau of Economic Research, "US Business Cycle Expansions and Contractions.” Available at http://www.nber.org/cycles/cyclesmain.html.

National Urban League, “Achieving Fairness and Efficiency in Unemployment Insurance.” Washington, DC: National Urban League Policy Institute, June 2010.

O’Leary, Christopher J., Unemployment Insurance Earnings Deduction Project: Final Report. Olympia, WA: Washington State Employment Security Department, September 1997.

O’Leary, Christopher J., “Policies for Displaced Workers: An American Perspective.” Report prepared for Human Resources and Skills Development Canada, March 2010.

Page, Marianne, Ann Huff Stevens, and Jason Lindo, "Parental Income Shocks and Outcomes of Disadvantaged Youth in the United States.” In The Economics of Disadvantaged Youth, edited by Jonathan Gruber. Chicago: University of Chicago Press, 2009. Pp. 213-235.

Shaefer, H. Luke and Liyun Wu, “A Changing Safety Net? Unemployment Insurance and LowSkilled Single Working Mothers After Welfare Reform.” Manuscript, June 17, 2010.

U.S. Department of Labor, “Unemployment Insurance Data Summary.” Washington, DC:

Employment and Training Administration. Available at: http://www.oui.doleta.gov/unemploy/content/data.asp 
U.S. Department of Labor, "DOL-ETA Information Related to the American Recovery and Reinvestment Act of 2009.” Available at http://www.doleta.gov/recovery/. Accessed September 13, 2010.

Vroman, Wayne, "Unemployment Insurance Solvency.” Presentation to the National Academy of Social Insurance Unemployment Insurance Roundtable, Washington, DC, July 13, 2010.

Whitehouse, Mark, "Some Firms Struggle to Hire Despite High Unemployment.” The Wall Street Journal, August 9, 2010. 


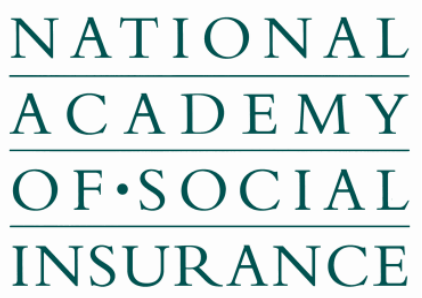

Strengthening Unemployment Insurance for the 21 $1^{\text {st }}$ Century A National Roundtable Sponsored by

The National Academy of Social Insurance with the Department of Labor, the Annie E. Casey Foundation, the W.E. Upjohn Institute for Employment Research and the DirectEmployers Association

$$
\begin{gathered}
\text { July } 13,2010 \\
\text { 9:30 am - 4:30 pm } \\
\text { Hall of States, } 444 \text { North Capitol Street NW } \\
\text { Washington, DC }
\end{gathered}
$$

9:30am Conference Welcome

Margaret Simms, The Urban Institute

9:35am Panel 1: Unemployment Insurance Administration

Margaret Simms, The Urban Institute (Moderator)

Gay Gilbert, U.S. Department of Labor

Rochelle Webb, Arizona Department of Economic Security

10:15am Panel 2: Views of Stakeholders

Charles Betsey, Howard University (Moderator)

Douglas J. Holmes, UWC - Strategic Services of Unemployment and

Workers' Compensation

Andrew Stettner, National Employment Law Project

11:00am Break

11:10am Panel 3: Eligibility Requirements and Benefit Adequacy

Harry Holzer, Georgetown University and the Urban Institute (Moderator)

Till von Wachter, Columbia University

Luke Shaefer, University of Michigan

Noon Lunch

12:30pm Luncheon Speaker

Jane Oates, Assistant Secretary of Employment and Training Administration, U.S. Department of Labor

Q\&A 
1:00pm Panel 4: The UI Payroll Tax: Forward Funding and Experience Rating Erica Groshen, Federal Reserve Bank of New York (Moderator)

Patricia Anderson, Dartmouth College

Gary Burtless, The Brookings Institution

1:45pm Panel 5: Solvency of Unemployment Insurance

Ralph Smith, Congressional Budget Office (retired) (Moderator)

Rich Hobbie, National Association of State Workforce Agencies

Wayne Vroman, The Urban Institute

2:30pm Break

2:45pm Panel 6: Getting Workers Back to Work

Roberta Gassman, Wisconsin Department of Workforce Development (Moderator)

Bill Warren, DirectEmployers Association

Dan Black, Harris School, University of Chicago

Christopher O'Leary, W.E. Upjohn Institute

3:30pm Panel 7: Further Discussion and Proposals for Sweeping Reform Joseph Quinn, Boston College (Moderator)

4:15pm Wrap up

Margaret Simms, The Urban Institute

Stephen Woodbury, Michigan State University and W.E. Upjohn Institute 


\section{Strengthening Unemployment Insurance for the $21^{\text {st }}$ Century}

\section{List of Roundtable Participants (in alphabetic order)}

\author{
Patricia Anderson \\ Dartmouth College \\ Michael Belitzky \\ State of Florida, Washington Office \\ Charles Betsey \\ Howard University \\ Dan Black \\ University of Chicago \\ Heather Boushey \\ Center for American Progress \\ Laura Boyett \\ Maine Department of Labor \\ Margot Brandenberg \\ Rockefeller Foundation \\ Michael Branson \\ Office of Management and Budget \\ Alex Brill \\ American Enterprise Institute \\ Gary Burtless \\ Brookings Institution \\ Tom Crowley \\ U.S. Department of Labor \\ Barbara DesMarteau \\ U.S. Department of Labor \\ Indivar Dutta-Gupta \\ House Committee on Ways and Means \\ Roberta Gassman \\ Wisconsin Department of Workforce \\ Development \\ Gay Gilbert \\ U.S. Department of Labor
}

Wayne Gordon

U.S. Department of Labor

Andrew Grant-Thomas

Kirwan Institute

Janice Gregory

National Academy of Social Insurance

Erica Groshen

The Federal Reserve Bank of NY

Darrick Hamilton

New School for Social Research

Diedra Henry-Spires

Senate Committee on Finance

Rich Hobbie

National Association of State Workforce

Agencies

Douglas Holmes

UWC

Harry Holzer

The Urban Institute

Carole Kitti

Office of Management and Budget

Linda Lawson

National Governors Association

Rick McHugh

National Employment Law Project

Nanine Mieklejohn

AFSCME

Mike Miller

U.S. Department of Labor

Roy Mulvaney

Montana Department of Labor \& Industry 


\author{
Demetra Nightingale \\ The Urban Institute \\ Diana Noel \\ National Conference of State Legislatures \\ Jane Oates \\ U.S. Department of Labor \\ Christopher 0'Leary \\ W.E. Upjohn Institute for Employment \\ Research \\ Rob Pavosevich \\ U.S. Department of Labor \\ Joseph Quinn \\ Boston College \\ Les Range \\ Mississippi Department of Employment \\ Security \\ Valerie Rawlston Wilson \\ National Urban League \\ Virginia Reno \\ National Academy of Social Insurance \\ Neil Ridley \\ CLASP \\ Christine Riordan \\ National Employment Law Project \\ Jesse Rothstein \\ U.S. Department of Labor \\ Luke Shaefer \\ University of Michigan \\ Andrew Sherrill \\ U.S. Government Accountability Office \\ Margaret Simms \\ The Urban Institute \\ Allison Slayton \\ National Employment Law Project
}

Ralph Smith

Congressional Budget Office (Retired)

Andrew Stettner

National Employment Law Project

Betsey Stevenson

U.S. Department of Labor

Bruce Vavrichek

Congressional Budget Office

Sandi Vito

Pennsylvania Department of Labor and Industry

Till von Wachter

Columbia University

Wayne Vroman

The Urban Institute

Anna Wadia

Ford Foundation

Stephen Wandner

U.S. Department of Labor

Bill Warren

DirectEmployers Association

Rochelle Webb

Arizona Department of Economic Security

Matt Weidinger

House Committee on Ways and Means

George Wentworth

National Employment Law Project

Julie Whittaker

Congressional Research Service

Ron Wilus

U.S. Department of Labor

Stephen Woodbury

W.E. Upjohn Institute for Employment

Research and Michigan State University 